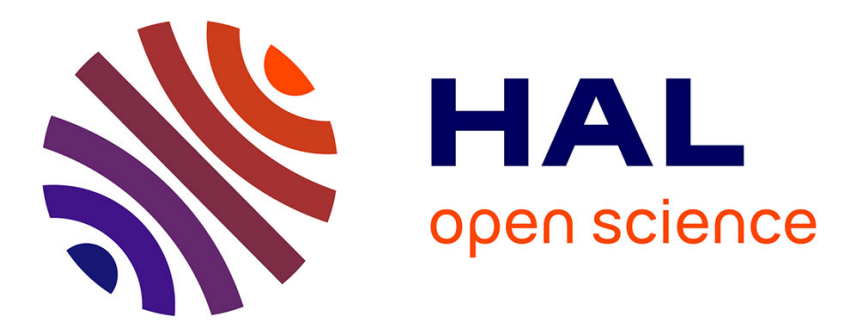

\title{
Early transformation and transfer processes in a Technosol developing on iron industry deposits
}

Hermine Huot, Marie-Odile Simonnot, Françoise Watteau, Philippe Marion, Jacques Yvon, P. de Donato, Jean-Louis Morel

\section{To cite this version:}

Hermine Huot, Marie-Odile Simonnot, Françoise Watteau, Philippe Marion, Jacques Yvon, et al.. Early transformation and transfer processes in a Technosol developing on iron industry deposits. European Journal of Soil Science, 2014, 65 (4), pp.470-484. 10.1111/ejss.12106 . hal-01021454

\section{HAL Id: hal-01021454 https://hal.science/hal-01021454}

Submitted on 26 Sep 2017

HAL is a multi-disciplinary open access archive for the deposit and dissemination of scientific research documents, whether they are published or not. The documents may come from teaching and research institutions in France or abroad, or from public or private research centers.
L'archive ouverte pluridisciplinaire $\mathbf{H A L}$, est destinée au dépôt et à la diffusion de documents scientifiques de niveau recherche, publiés ou non, émanant des établissements d'enseignement et de recherche français ou étrangers, des laboratoires publics ou privés. 


\title{
Early transformation and transfer processes in a Technosol developing on iron industry deposits
}

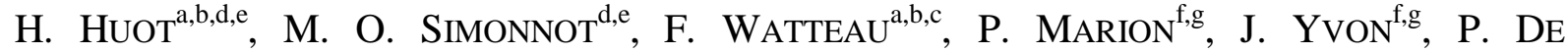 \\ DONATO $^{\text {f,g }} \&$ J. L. MOREL ${ }^{\text {a,b }}$ \\ ${ }^{a}$ Université de Lorraine, Laboratoire Sols et Environnement, UMR 1120, Vandoeuvre-lès- \\ Nancy, F-54518, France, ' INRA, Laboratoire Sols et Environnement, UMR 1120, \\ Vandoeuvre-lès-Nancy, F-54518, France, ${ }^{c}$ CNRS, UMS 3562, Vandoeuvre-lès-Nancy F- \\ 54501, France, ${ }^{\mathrm{d}}$ Université de Lorraine, Laboratoire Réactions et Génie des Procédés, UMR \\ 7274, Nancy, F-54001, France, ${ }^{\mathrm{e}}$ CNRS, Laboratoire Réactions et Génie des Procédés, UMR \\ 7274, Nancy, F-54001, France, ${ }^{\mathrm{f}}$ Université de Lorraine, GéoRessources, UMR 7359, \\ Vandoeuvre-lès-Nancy, F-54 518, France, and ${ }^{\mathrm{g}}$ CNRS, GéoRessources, UMR 7359, \\ Vandoeuvre-lès-Nancy, F- 54 518, France
}

Correspondence: H. Huot.E-mail: hermine.huot@yahoo.fr

\section{Summary}

Large surface areas covered with man-made materials are subject to pedogenetic evolution. However, pedogenetic processes in the resulting Technosols are seldom fully assessed. This work was conducted to identify and characterize the processes occurring on deposits of industrial technogenic materials.

A former settling pond of the iron and steel industry was chosen where a forest has established since termination of the industrial activity, approximately 50 years ago. A 2-m deep pit was opened, and a series of layers of the soil profile were sampled. Macro- and micro-structure were studied, and soil samples were analysed for structural, chemical and mineralogical assessment (chemical analyses, X-ray diffraction, infrared and Mössbauer spectroscopies, scanning and transmission electron microscopies coupled with energy dispersion spectrometry).

Results showed that the profile was composed of a succession of sub-horizontal layers arranged in two groups according to their structure and composition linked to the composition of the industrial effluent. Group 1 was composed of iron-, carbonate- and aluminosilicate-rich layers exhibiting a compact structure. Group 2 contained manganese-rich layers with a friable structure. Pedogenetic processes of various intensities were detected at different depths. Besides an accumulation of organic matter at the surface, transformations of minerals were recorded all along the soil profile, with weathering, leaching and precipitation of new phases. Phenomena occurred primarily in specific zones, such as cracks and interfaces between two layers. In conclusion, the soil maintained characteristics of the original industrial material and displayed several stages of pedogenesis, which were controlled chronologically by climatic and biological factors. 


\section{Introduction}

In densely populated areas, human pressure has become the main factor of soil pedogenesis. Human activities affect soil formation through the generation of technogenic parent materials and changes in soil evolution conditions (De Kimpe \& Morel, 2000). Technosols are a soil group of the World Reference Base for Soil Resources (WRB; IUSS Working Group WRB, 2006) taking into account soils wherein properties and pedogenesis are dominated by their technogenic origin (Lehmann, 2006; Rossiter, 2007). They include a large range of soils and especially those developing on industrial or urban wastes (landfills, sludge, cinders, mine spoils and ashes).

In a similar way to natural bedrock, technogenic parent materials originating from man's activities may undergo a set of physical, chemical and biological processes under the influence of pedogenetic factors: climate, biological activity, topography and time (Jenny, 1941). In contrast to most natural environments, pedogenesis is recent, and affects young and heterogeneous materials originating from man's activities. Intense and rapid weathering seems to be a common feature of Technosols when compared with natural soils (Zevenbergen et al., 1999; Rossiter, 2007; Séré et al., 2010). Little is known about the pedogenetic processes that affect technogenic materials, and pedogenesis is often considered as unimportant because of the short period of development. Understanding the processes of evolution of Technosols would provide useful knowledge about the changes in man-made materials, which may contain toxic compounds, under the influence of the environmental factors and their impact on adjacent environments (water bodies, natural ecosystems) and add to our general understanding about processes affecting soil development.

Different processes have been described in Technosols. Accumulation of organic matter at the soil surface is often reported as the primary pedogenetic process that occurs in them (Sourkova et al., 2005). Also, solute movement (carbonates, sulphates) as well as changes in structure and hydrodynamics have been shown to occur (Zikeli et al., 2002; Hartmann et al., 2010; Séré et al., 2010) and specific aggregation phenomena involving mineral and organic technogenic materials have been demonstrated (Monserié et al., 2009; Séré et al., 2010). However, transformations of minerals are rarely considered despite their value as indicators of pedogenesis (Uzarowicz \& Skiba, 2011). In general, investigations about the weathering of industrial materials (metallurgy by-products, incineration residues, smelter-derived particles) are conducted within a context of risk assessment related to pollutant fate and impact. Nevertheless, these studies may also reveal strong mineral transformations of primary phases and the formation of secondary phases (Ettler et al., 2001; 2003).

Pedogenetic processes can be assessed from detailed studies of the soil profile, in comparison with unaltered material parents (Van Breemen \& Buurman, 2002). In contrast to natural soils, this approach is more difficult with Technosols because of the unknown initial composition of the source materials (such as industrial sludge), strong heterogeneity (several depositing events) and a short period of pedogenesis (a few decades). Therefore, pedogenesis assessment of Technosols must rely on changes in a large set of properties. First, characterization of the mineral constituents and their transformations, together with historical information are useful tools to trace the industrial processes (Vassilev \& Vassileva, 1996; Gregurek et al., 1998). Mineralogical approaches can be used to describe weathering 
sequences of by-products under natural conditions and to predict their long-term behaviour (Yvon et al., 2006; Saffarzadeh et al., 2011). Finally, analysis of the soil structure at several scales (from profile to micro-structure) may provide a large range of information on the physical, chemical and biological processes occurring in the Technosol (Bullock et al., 1985).

A Technosol that developed in a former settling pond of the iron industry and covered by a forest ecosystem was studied as a relevant model to understand the process of pedogenesis better. In a previous examination of this Technosol, bulk chemical and physical properties were characterized (Huot et al., 2013). The chemical (large CEC, alkaline pH) and physical properties (low bulk density, large micro-porosity, strong water retention capacity) indicated that the soil was a Spolic Technosol (Calcaric, Laxic, Hydric, Thixotropic, Andic, Toxic) (IUSS Working Group WRB, 2006). A strong vertical heterogeneity in composition was recorded along the profile, resulting from the successive sludge deposits. The structure and composition of materials seemed to be mostly derived from the former industrial processes; however, some indication of mineral weathering and solute transfer were detected in the soil profile.

Here we report efforts to identify and characterize the pedogenetic processes that occurred in the early stages of evolution of this very complex Technosol. General methods were based on the study of the soil constitution at several scales and the characterization of mineral constituents in order to distinguish processes directly connected to the iron and steel industry, and processes which could be attributed to early pedogenesis of the Technosol.

\section{Materials and methods}

\section{History of the site and the industrial processes}

The iron and steel industry of Pompey-Frouard-Custines (Lorraine, France), situated along the Moselle river, existed from 1872 to 1986 and it produced special and well-known pig iron and steels. In particular, a manganese (Mn)-rich ferroalloy (ferromanganese) was made in one blast furnace from 1922 until the industry ceased (Truffaut, 2004).

During pig iron production, the gas leaving the blast furnace contains particulates and so requires cleaning before recycling. Generally, dry cleaning to remove coarser particles is followed by wet cleaning which is commonly performed by spraying water into the gas to capture finer particles. Sludge resulting from wet cleaning is not recycled because it contains zinc $(\mathrm{Zn})$, lead $(\mathrm{Pb})$ and alkali metals that can damage the blast furnace. Therefore, the sludge is often dumped into settling ponds (Mansfeldt \& Dohrmann, 2004).

In Pompey, the sludge was transported by pipe to the settling ponds situated on an island at the confluence of the Meurthe and Moselle rivers. Generally, dams were gradually built with slag or other materials around ponds during the filling by successive sludge supplies, thereby generating stratified deposits about $10-\mathrm{m}$ deep. The pond in the southwestern part of the island has a surface area of 2.6 ha. The alluvial groundwater table is at 7-8 $\mathrm{m}$ from the pond surface. It is assumed that sludge dumping was abandoned in the 1950s. The site was restored after the industry closed for further economic development (Schwartz et al., 2001). However, the former settling pond remained unchanged and was colonized by vegetation leading to a forested ecosystem. 


\section{Profile description and samplings}

A 2-m deep pit was opened in June 2009 in the north-western flat part of the pond (48 46'6.98'N, 6 8'6.47'E) (Huot et al., 2013). The pit was in a small clearing covered by herbaceous species and surrounded (more than $1.5 \mathrm{~m}$ from the pit) by deciduous woody species (Sambucus nigra L., Populus tremula L., Betula pendula L.). Colours of the different layers of the profile were assessed with the Munsell Soil Color Chart. According to the Référentiel Pédologique (AFES, 2008), the soil displayed an A/C profile with a $\mathrm{C}$ horizon composed of numerous layers of various colours.

Among the 24 layers visible in the 2-m pit, 12 were selected as representative of the whole soil profile, and, except for the A horizon, layers of the $\mathrm{C}$ horizon were chosen for their contrasting colours and structure (Figure 1). Layers were sampled in May 2010 for chemical analyses and mineralogical characterization. Blocks of undisturbed soil samples were also collected using Kubiena boxes $(90 \times 60 \times 50 \mathrm{~mm})$ at eight depths, within layers or at the interface between layers (Figure 1). Kubiena boxes with two open faces were slowly inserted into a ledge excavated at the desired depth in the soil. After extraction from the soil with a knife, the boxes were wrapped, secured against any disturbance in a container and transported to the laboratory.

To determine cyanide contents in the soil, samples were collected in March 2004 in an older pit in the north-eastern part of the pond. Four layers were collected at $35-40 \mathrm{~cm}$ (corresponding to layer 2), 40-55 cm, 55-70 cm (corresponding to layer 3) and at 70-80 cm (corresponding to layer 4).

(a)

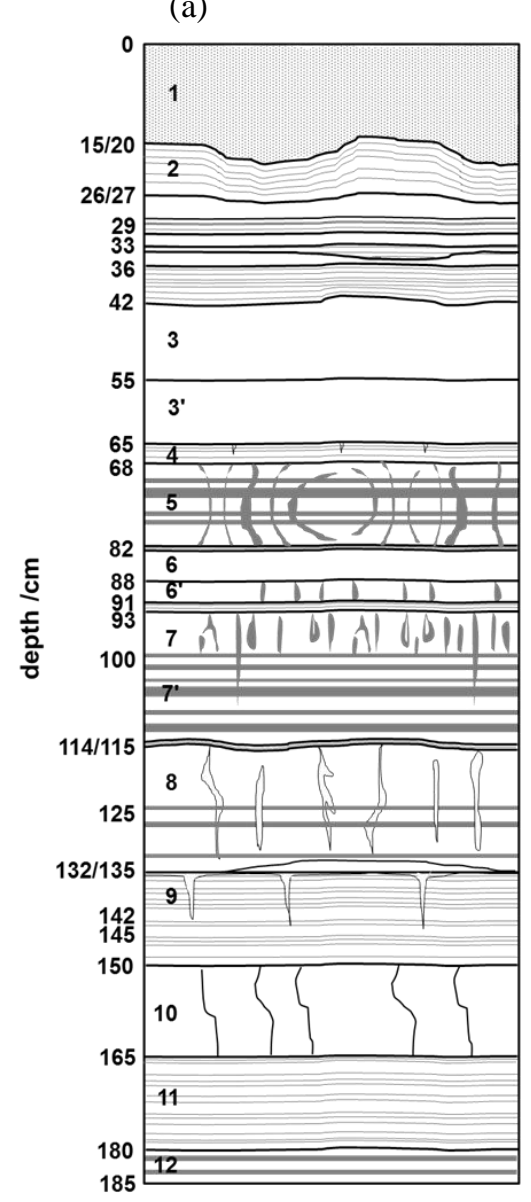

(b)

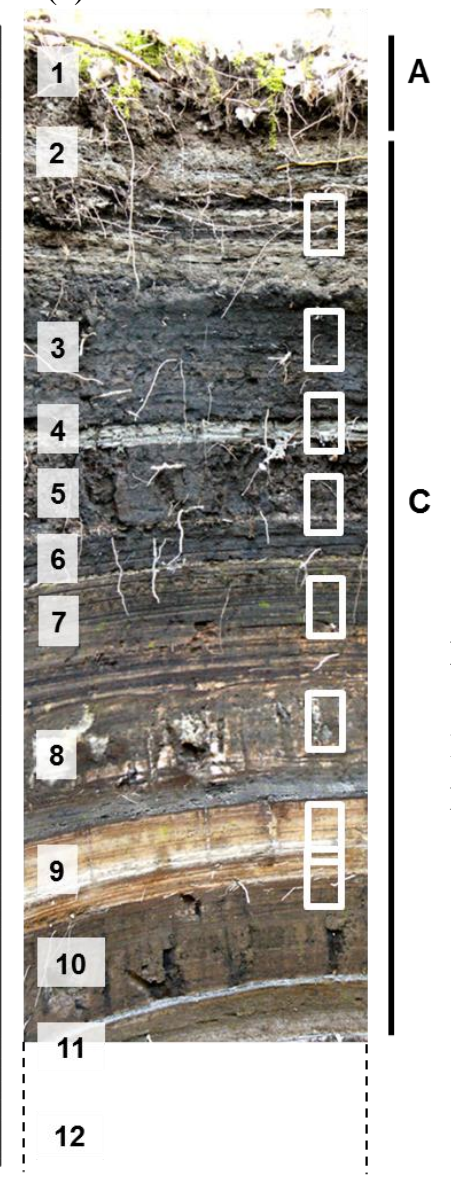

A

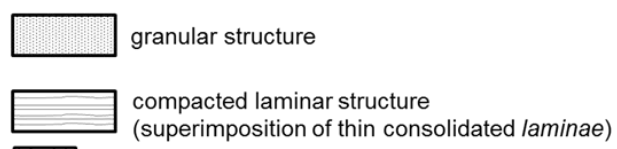

$\$$ with cracks

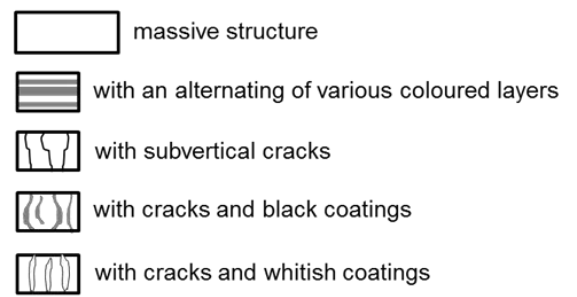

Figure 1 The Technosol profile with the 12 selected layers: (a) variation in layer limits and structure along the Technosol profile and (b)A/C profile showing the 12 selected layers with the location of samples for thin sections. 


\section{Thin sections}

Thin sections were prepared from blocks of undisturbed soil. Blocks were dried with acetone and embedded in resin and polymerized at $35^{\circ} \mathrm{C}$, and $30 \mu \mathrm{m}$-thick sections $(50 \times 80 \mathrm{~mm})$ were extracted from each block. Some cracks appeared during drying. A general description of thin sections was made at $8 \times$ and in more detail at $60 \times$ magnification with a stereomicroscope Leica MZ FLIII (Leica Microsystems AG, Heerbrugg, Switzerland). Conventional descriptions were made following guidelines recommended by Bullock et al. (1985) and Stoops et al. (2010) including the assessment of mineral and organic phases, porosity, micro-structures and pedo-features. Specific structural features were further analysed with a scanning electron microscope JSM J7600F (JEOL, Tokyo, Japan) equipped with an analysis system EDS (20 $\mathrm{mm}^{2}$ of SDD type) coupled with a spectrometer WDS INCA (Oxford Instruments, Oxfordshire, United-Kingdom) on some areas of the thin sections after thin carbon coating.

\section{Chemical analyses}

The 12 sampled layers were freeze-dried and ground manually with an agate mortar for chemical and mineralogical analyses. Elemental composition was performed by the Service d'Analyse des Roches et des Minéraux (CNRS, Vandoeuvre-lès-Nancy) according to the method described by Carignan et al. (2001). Major elements are reported in the Table 1. Forms of aluminium ( $\mathrm{Al}$ ), iron ( $\mathrm{Fe}$ ), silicon ( $\mathrm{Si}$ ) and $\mathrm{Mn}$ were determined according to the methods of Tamm (1922) and Mehra \& Jackson (1960) by the Laboratoire d'Analyse des Sols (INRA, Arras), as described in Huot et al. (2013).

Analysis of total cyanides was conducted on four layers in 2004 according to the standard method described by AFNOR XP X31-430 (2001). Available cyanides, which include cyanide compounds in a solid that can form $\mathrm{HCN}$ during the distillation at $\mathrm{pH} 4$ (AFNOR XP X31-430, 2001), were determined on the soil sample collected at 70-80 cm (corresponding to layer 4).

Table 1 Major elements (\%) in the 12 selected layers along the Technosol profile. Two groups of deeper layers were defined according to their morphology and structure.

\begin{tabular}{cccccccc}
\hline Layer & $\begin{array}{c}\text { Layer } \\
\text { group }\end{array}$ & $\begin{array}{c}\text { Depth } \\
\text { /cm }\end{array}$ & \multicolumn{5}{c}{$\begin{array}{c}\text { Major elements } \\
\text { /\% (w/w) }\end{array}$} \\
\hline 1 & - & $0-18$ & $\mathrm{Fe}: 21.0$ & $\mathrm{C}: 14.0$ & $\mathrm{Ca}: 8.4$ & $\mathrm{Si}: 6.2$ & $\mathrm{Al}: 3.6$ \\
2 & 1 & $18-26$ & $\mathrm{Fe}: 13.0$ & $\mathrm{Ca}: 12.0$ & $\mathrm{Si}: 10.0$ & $\mathrm{C}: 4.0$ & $\mathrm{Al}: 5.8$ \\
3 & 2 & $42-55$ & $\mathrm{Mn}: 27.0$ & $\mathrm{Ca}: 8.1$ & $\mathrm{Si}: 5.7$ & $\mathrm{Al}: 5.6$ & $\mathrm{C}: 3.5$ \\
4 & 1 & $65-68$ & $\mathrm{Ca}: 19.0$ & $\mathrm{Si}: 12.0$ & $\mathrm{C}: 9.5$ & $\mathrm{Al}: 5.4$ & $\mathrm{Zn}: 2.9$ \\
5 & 2 & $68-82$ & $\mathrm{Mn}: 34.0$ & $\mathrm{Ca}: 7.0$ & $\mathrm{Si}: 6.2$ & $\mathrm{Al}: 4.1$ & $\mathrm{C}: 1.9$ \\
6 & 2 & $82-91$ & $\mathrm{Mn}: 26.0$ & $\mathrm{Ca}: 8.8$ & $\mathrm{Si}: 8.2$ & $\mathrm{Al}: 4.1$ & $\mathrm{C}: 2.8$ \\
7 & 2 & $93-112$ & $\mathrm{Mn}: 19.0$ & $\mathrm{~Pb}: 11.0$ & $\mathrm{Si}: 8.8$ & $\mathrm{Fe}: 6.2$ & $\mathrm{Ca}: 5.5$ \\
8 & 2 & $112-134$ & $\mathrm{Mn}: 21.0$ & $\mathrm{Ca}: 15.0$ & $\mathrm{Si}: 5.4$ & $\mathrm{C}: 4.0$ & $\mathrm{Al}: 3.4$ \\
9 & 1 & $135-150$ & $\mathrm{Ca}: 12.0$ & $\mathrm{Si}: 11.0$ & $\mathrm{Mn}: 7.0$ & $\mathrm{Fe}: 5.6$ & $\mathrm{Al}: 5.6$ \\
10 & 2 & $150-165$ & $\mathrm{Mn}: 18.0$ & $\mathrm{Ca}: 11.0$ & $\mathrm{Si}: 8.2$ & $\mathrm{Fe}: 5.5$ & $\mathrm{Al}: 4.9$ \\
11 & 1 & $165-180$ & $\mathrm{Ca}: 16.0$ & $\mathrm{Fe}: 12.0$ & $\mathrm{Si}: 9.3$ & $\mathrm{C}: 9.2$ & $\mathrm{Al}: 3.8$ \\
12 & 1 & $>180$ & $\mathrm{Ca}: 13.0$ & $\mathrm{Zn}: 8.1$ & $\mathrm{Si}: 7.9$ & $\mathrm{Fe}: 6.0$ & $\mathrm{C}: 5.9$ \\
\hline
\end{tabular}




\section{Mineralogical analyses}

X-ray diffraction (XRD) was performed by reflection on randomly dispersed powders, using a diffractometer Bruker D8 Advance (Bruker, Karlsruhe, Germany) with Co K $\alpha$ radiation ( $\lambda=$ 1,789 $\AA$ ) in the Laboratoire Interdisciplinaire des Environnements Continentaux (CNRS-UL, Vandoeuvre-lès-Nancy). Diffuse reflection infrared Fourier transform spectroscopy (DRIFTS) was conducted with a Bruker Equinox IFS 55 device (Bruker, Ettlingen, Germany), after dilution in $\mathrm{KBr}$, without preparing pellets, in the Laboratoire Géoressources (CNRS-UL, Vandoeuvre-lès-Nancy).

These global characterizations were completed by observations and elemental analyses on six samples (layers 1, 2, 4, 5, 7 and 11) by scanning electron microscopy (SEM) and transmission electron microscopy (TEM) coupled with energy dispersion spectrometry (EDS). Analysis by SEM-EDS was performed on polished sections after vaporization of a thin carbon layer with a SEM S-4800 (Hitachi, Japan) equipped with a EDS Si(Li) diode (Noran, Middleton, USA) and the SEM JSM J7600F. Images were obtained in back-scattered electron (BSE) mode. Analysis by TEM-EDS was carried out on samples dispersed in ethanol and deposited on carbon films supported by $\mathrm{Cu}$ grids, using a TEM CM20 (FEI, USA) equipped with a EDS Si(Li) diode (PGT, Princeton, USA) at $200 \mathrm{kV}$. The microscopy analyses were conducted in the Service Commun de Microscopie Electronique et de Microanalyses (CNRSUL, Vandoeuvre-lès-Nancy).

The three most Fe-rich samples (layers 1, 2 and 11) were subjected to Mössbauer analysis in the Laboratoire de Chimie Physique et Microbiologie pour l'Environnement (CNRS-UL, Vandoeuvre-lès-Nancy) using a constant acceleration spectrometer and a 512 multichannel analyser, (Halder Elektronic $\mathrm{GmbH}$, Seehausen, Germany), a scintillation detector (Crismantec, St Pierre-lès-Nemour, France) and a $50 \mathrm{mCi}$ source of ${ }^{57} \mathrm{Co}$ in $\mathrm{Rh}$ matrix maintained at room temperature. The velocity was calibrated with a $25 \mu \mathrm{m}$ foil of $\alpha$-Fe at room temperature and the centre shifts are given with respect to this reference. Samples were placed in the sample holder and introduced into the cryostat (Advanced Research Systems, Macungie Pennsylvania, USA). After the amount of sample materials had been optimized (10 $\mathrm{mg} \mathrm{Fe} \mathrm{cm}^{-2}$ ), spectra were computed and fitted by $\chi^{2}$ minimization using a sum of Lorentzian shape lines as implemented in the Recoil software. Measurements were performed with a velocity range of $\pm 11 \mathrm{~mm} \mathrm{~s}^{-1}$. The larger range allowed possible detection of magnetically split patterns from Fe oxides.

\section{Results}

\section{Soil structure (from the profile scale to the micro-morphology)}

The Technosol profile was composed of a superimposition of sub-horizontal layers of various colours, thickness and structure. At the profile scale, layers were clearly delimited. However, in some cases wavy limits between layers were observed (limit 1/2 or 7'/8) (Figure 2b) and series of cracks ( 2 to 5 -mm wide and a few $\mathrm{cm}$ deep) were detected at some interfaces between layers (limit 8/9). In general, cracks were filled with fine materials originating from the layers above (layer 4) (Figure 3c). Roots were present throughout the profile with a 
varying density according to the layer (Figure 1a). The 20-cm thick surface layer exhibited a granular structure, a brown colour (5 YR 2.5/2) and a large root density (data not shown).
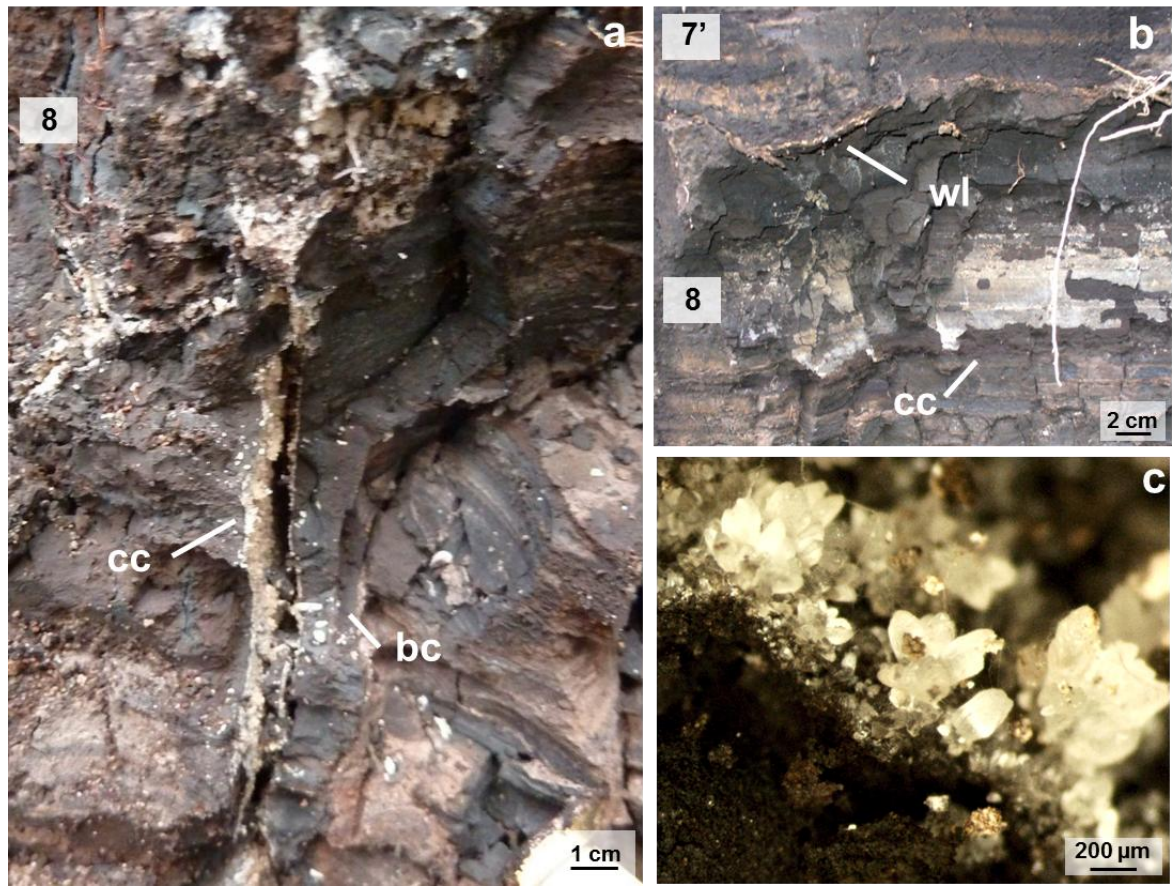

Figure 2 Structure in layer $8 \quad(112-134 \mathrm{~cm})$ (group 2) featured by cracks with calcitic coatings: (a) crack in layer 8 with black coating and calcite deposit inside the crack, (b) calcite coatings in layer 8 and the wavy limit between layers 7' and 8 and (c) calcite coatings comprising crystals. cc : calcitic coating; bc : black coating ; wl : wavy limit.
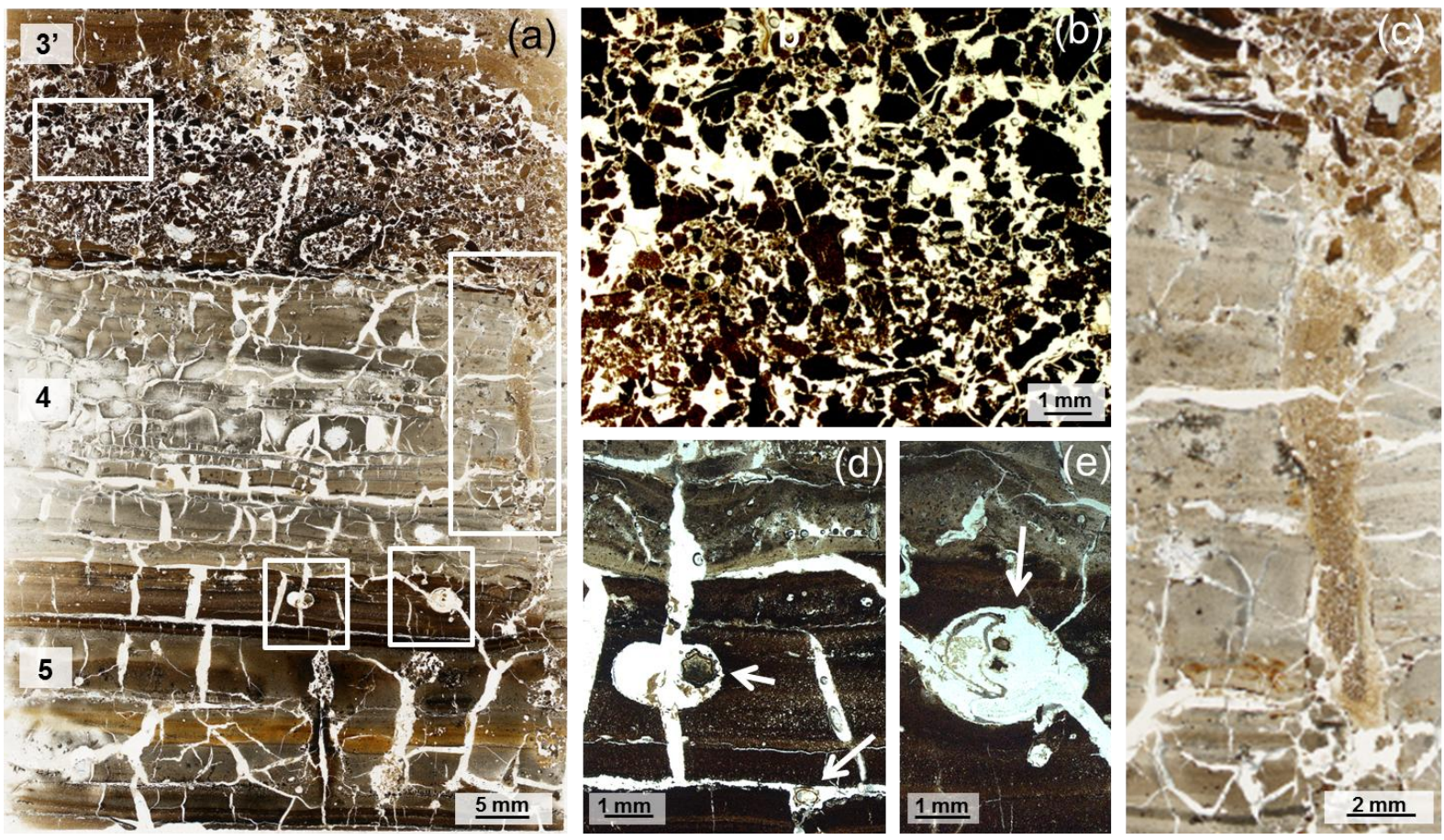

Figure 3 Structure in layer 4 (group 1) and at the limits with the surrounding layers (3' and 5) (group 2). Microstructure was observed in a thin section with a stereomicroscope: (a) whole thin section $(63-71 \mathrm{~cm})$ with the locations of the detailed pictures, (b) particular structure of layer 3' composed of 100 to $1500 \mu \mathrm{m}$ particles, (c) crack in layer 4 filled with the finer material from above layer 3', (d) roots in macropores and between two laminae in layer 5 and (e) biodegraded root in macropore under the limit of layers 4 and 5 . 
Deeper in the profile, light layers with compacted laminar structure (a few $\mathrm{mm}$ to $15-\mathrm{cm}$ thick) alternated with dark layers with massive structure (one to 20-cm thick) (Figure 1b). Two groups of deeper layers could be identified. Group 1 (layers 2, 4, 9 and 11) included layers with a laminar structure resulting from the superimposition of millimetric consolidated laminae. They were various shades of grey (10 YR 7/1 to $7.5 \mathrm{YR} 4 / 0$ ), rust (10 YR 5/6 to 5 YR 3/3) and beige (10 YR 8/1-8/2 to 7.5 YR 8/0-8/2). Their composition was dominated by calcium $(\mathrm{Ca})$ or Fe (Table 1). Layer 12 could be linked to this group regarding its composition despite its crumblier structure.

Group 2 was composed of crumbly layers (3, 5, 6, 7, 8 and 10). Most of them (layers 3, 5, 8 and 10) were uniformly coloured black (5 YR 3/1 to 10 YR 2/1), the others showed a succession of black and rust (10 YR 6/4 to $2.5 \mathrm{Y} 6 / 6$ ) laminae (layer 7') or the superimposition of thin laminae (one to $8-\mathrm{mm}$ thick) of rust to beige colours (7.5 YR 3/4 to $10 \mathrm{YR}$ 6/4 in the layer 5 and $10 \mathrm{YR} 5 / 3$ to $10 \mathrm{YR} 7 / 2$ in layer 8). Manganese was the major element of these layers (Table 1).

Micro-structure analysis showed the laminar structure of the materials of group 2 (Figure 3d). Also, it revealed areas with a particular structure composed of distinct particles (50-1500 $\mu \mathrm{m}$ ), especially in layers 3 and 6 (Figure 3b). Layers 5, 7, 8 and 10 exhibited more or less curved sub-vertical cracks with or without fillings (Figure 1b). Black coatings, composed of 0.5- to 3-mm thick black (10 YR 2/1 to $10 \mathrm{R} 2.5 / 2$ ) compacted and brittle materials, covered the faces of cracks in layers 5, 7 and 8 (Figure 4a-d-e). In the latter, a whitish coating (10 YR $6 / 3$ to 6/4) developed inside the cracks and on the faces of the blocky structures that they delimited (Figure 2a). This coating was composed of a fine layer of translucent crystals (100$500 \mu \mathrm{m})$ which reacted with acid $(\mathrm{HCl} 0.05 \mathrm{M})$ and might be a calcitic coating (Figure 2c). In some places, this formed a fine and delicate beige coating, which was also found in some cracks (5-cm deep) in the underlying layer 9. According to SEM-EDS elemental analyses of layer 7, the black coatings were more enriched in Mn and depleted in Si than the lighter material covered by the coating (Figure 5). The material of the black coatings seemed to diffuse inside the adjacent lighter materials (Figure 5a). This phenomenon was recorded on the rims of the cracks (Figure 4e), around large black nodules and at the limits between two laminae (Figure 4b). Diffusion from the darker layers towards the lighter ones formed black dendrites upward or black droplets downward (Figure 4c-g-h). This effect followed the stratification and its deformation or added to the pre-existing stratification (layer 9) (Figure 4f). Spherical black or rust nodules (50-200 $\mu \mathrm{m}$ in diameter) were present in the lighter layers 4, 7, 9, 10 and 11 (Figure 4c). Their composition was dominated by Mn and they contained also substantial amount of Fe, according to SEM-EDS elemental analyses (layers 7 and 9).

The presence of roots as well as fecal pellets including Oribatid mites provided evidence of significant biological activity in most of the layers (layer 5) (Figure 3e). As expected, activity was more intense in the surface layer than deeper in the profile. The presence of a network of macro-pores (100 to more than $5000 \mu \mathrm{m}$ in diameter) was also recorded. Roots were often found in the macro-pores or at the limit between two laminae (Figure 3d). 

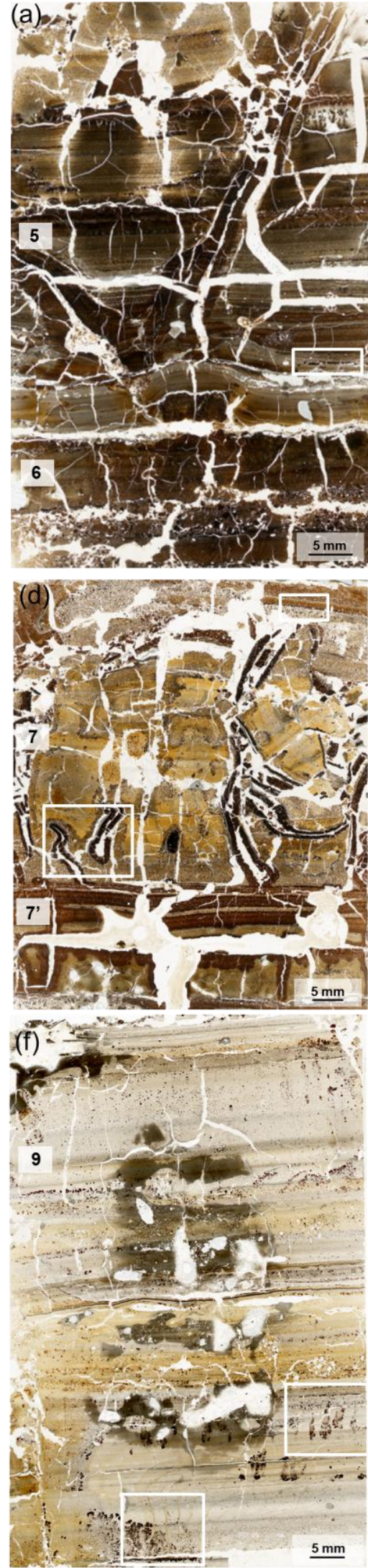
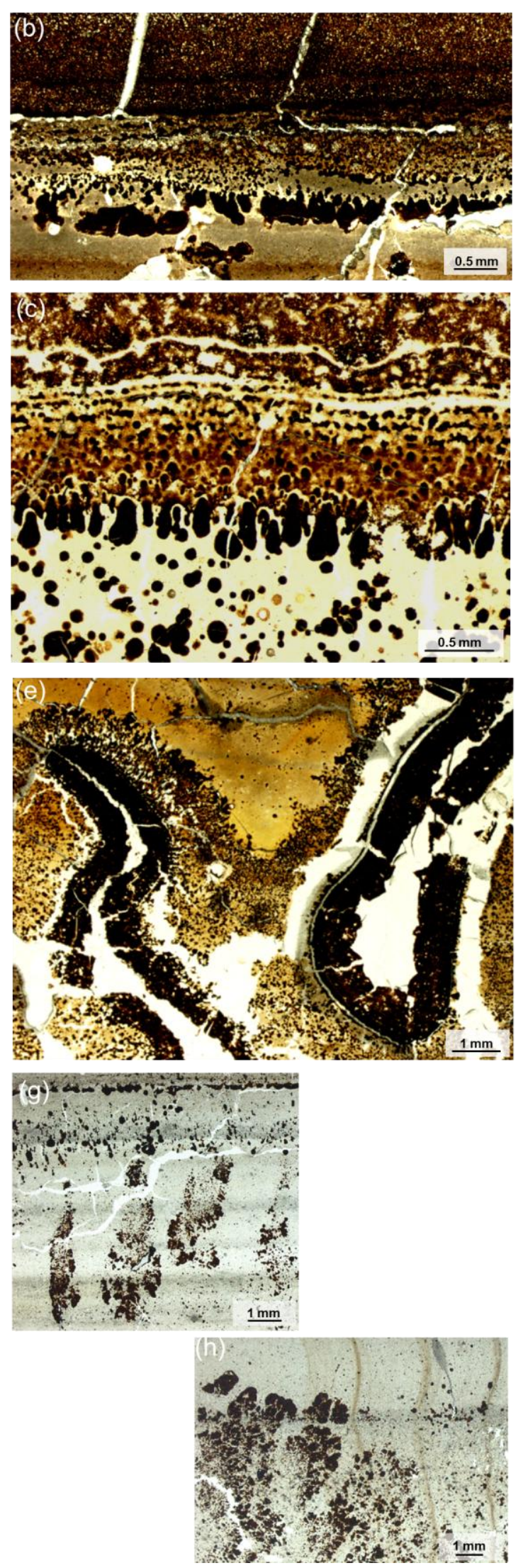

Figure 4 Black coatings in cracks, dendrites and droplets in layers 5, 7 (group 2) and 9 (group 1). Micro-structure was observed in thin sections with a stereomicroscope: (a) crack with black coating crossing over the laminar structure of layer 5: whole thin section, (b) black droplets at the limit of layer 5 and below fine laminar grey layer : detail of the thin section (a), (c) black droplets and nodules in layer 7: detail of the thin section (d), (d) cracks with black coatings in closed loop in layer 7 and laminar structure of layer 7': whole thin section, (e) black coatings in cracks and diffuse black precipitates around: detail of the thin section (d), (f) laminar structure in layer 9 with black figures of diffusion and nodules: whole thin section, (g) black precipitates with downward movement: detail of the thin section and (h) black precipitates with upward movement (dendrites) : detail of the thin section (f). 

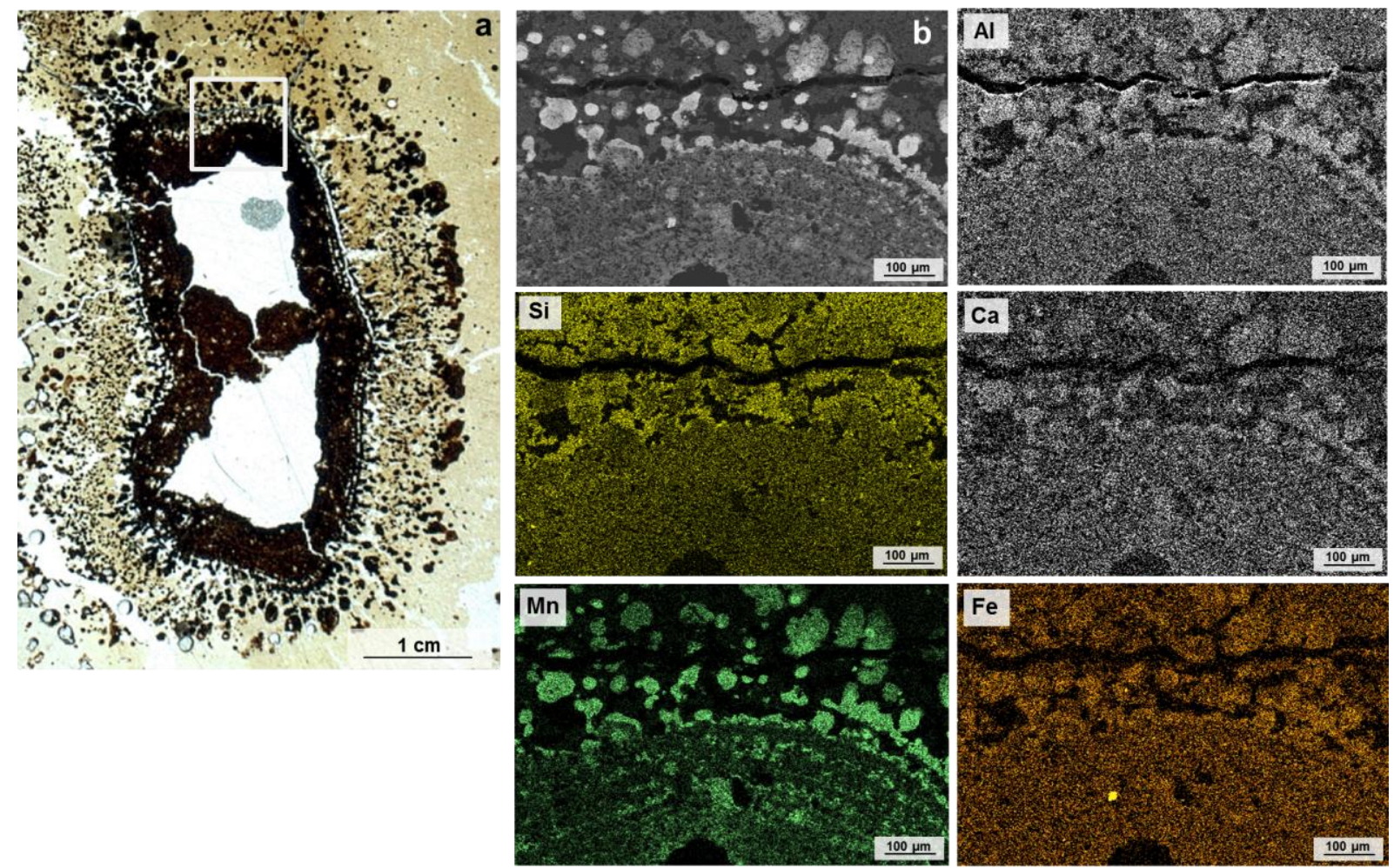

Figure 5 Observations and elemental map of the black coating in a crack in the layer 7 (group 2). The backscattered electron image (b) and the EDS X-ray map (Al, Si, Ca, Mn and Fe) obtained with SEM-EDS on the rim of a black coating and black nodules around on a thin section of layer 7 observed with a stereomicroscope (a).

\section{Mineralogy}

At the profile scale, groups determined according to the morphology were confirmed with mineralogical analysis. Group 1 layers (1, 2, 4, 9, 11 and 12) were dominated by carbonates, aluminosilicate phases and $\mathrm{Fe}$ (hydr)oxides in layers 2 and 11 and contained cyanide compounds. The surface layer displayed mineralogy similar to layer 2. Group 2 layers $(3,5,6$, 7, 8 and 10) had a large content of Mn (hydr)oxides, and sulphate phases were recorded only in the deepest layers $(7,8,9,11$ and 12) (Table 2). X-ray diffraction analyses revealed the weak extent of crystallinity of mineral phases in group 2 layers (3, 5, 6, 7, 8 and 10) (Figure 6). Also, numerous phases exhibited compositional zonings, while others resulted from the association of several phases.

Calcite $\left(\mathrm{CaCO}_{3}\right)$ was detected in all layers by XRD in variable amounts (Figure 6). Group 1 layers were generally more calcareous than group 2 . Layer 8 was an exception, as already reported (Huot et al., 2013). Calcite was present as individual crystals or as crystals around another phase (Figure 8a). 


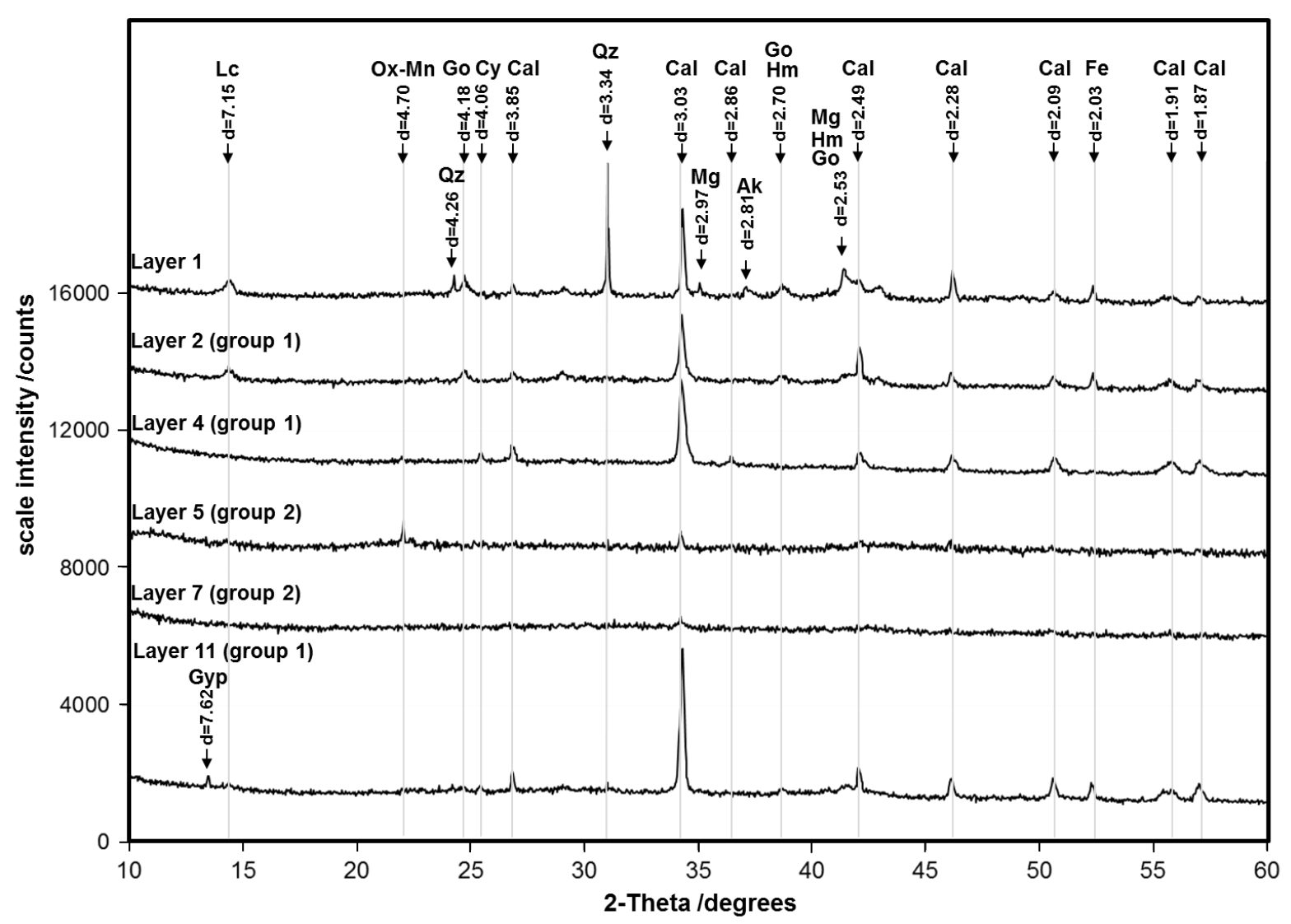

Figure 6 X-ray diffraction patterns for 6 selected layers $(1,2,4,5,7$ and 11) along the Technosol profile. Layer 1 is the organo-mineral surface layer. Layers 2, 4 and 11 belong to group 1, and layers 5 and 7 to group 2.

Ak: akermanite ; Cal: calcite ; Cy: cyanide compound ; Fe: metallic iron ; Go: goethite ; Gyp: gypsum ; Hm: hematite ; Lc: lamellar compound of the chlorite or kaolinite groups ; Mg: magnetite ; Ox-Mn: Mn oxide $\left(\mathrm{MnO}_{2}\right)$; Qz: Quartz. 
Table 2 Recap chart of the detected and observed mineralogical phases in the 12 selected layers along the Technosol profile. O: phase frequently observed by SEM-EDS and/or TEM-EDS; o: phase rarely observed by SEM-EDS and/or TEM-EDS; X: major phase detected by XRD, DRIFTS and/or Mössbauer spectroscopy; x: minor phase detected by XRD, DRIFTS and/or Mössbauer spectroscopy.

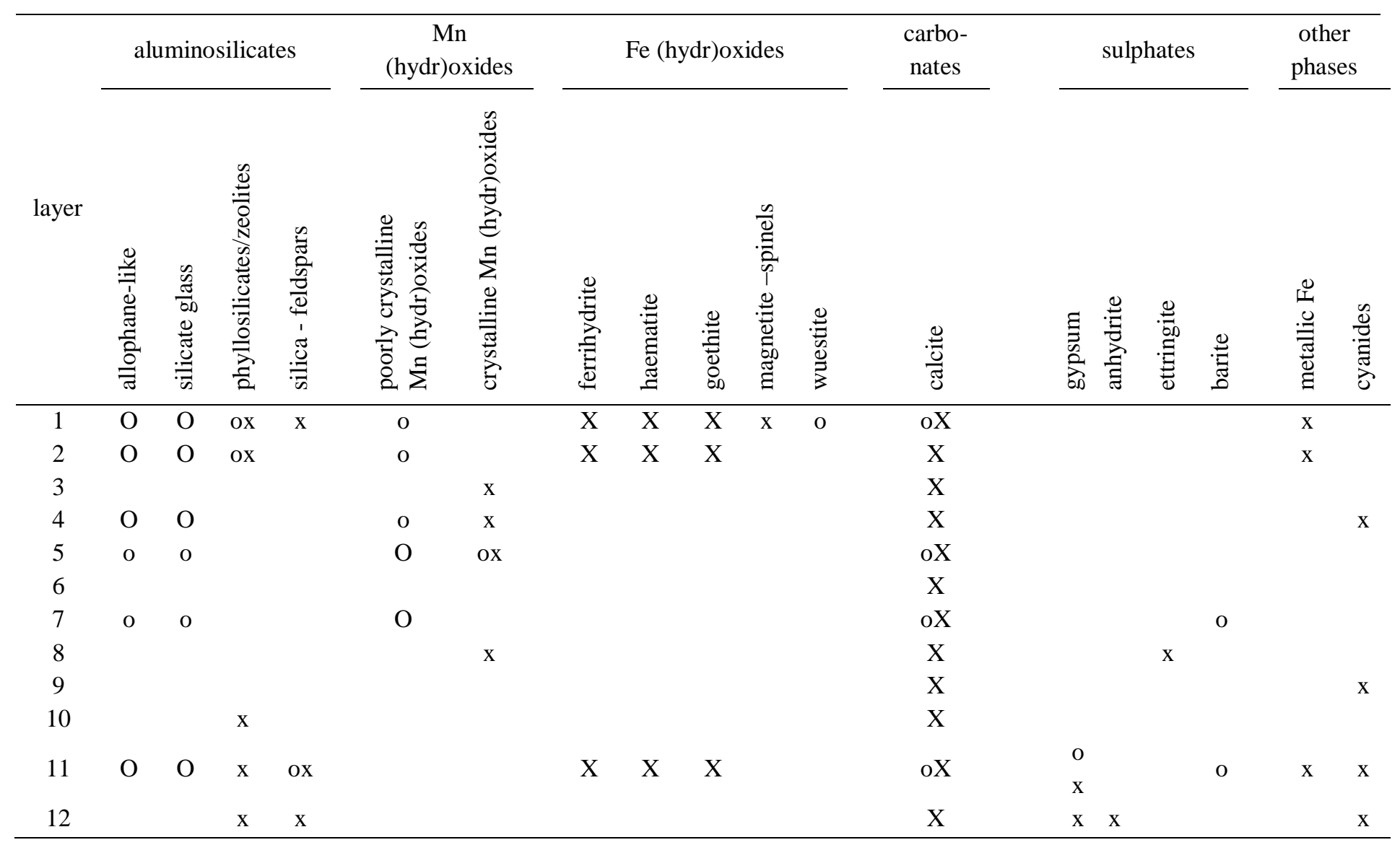


Tamm and Mehra-Jackson extractable- $\mathrm{Si}$ and $\mathrm{Al}$ contents indicated poorly crystalline oxalate-extractable aluminosilicates phases, assigned to 'allophane-like' phases as defined by Huot et al. (2013). Spherical and fibrous aluminosilicate phases were observed mainly in layers 1, 2, 4 and 11 (group 1) and as minor phases in layers 5 and 7 (group 2) (Table 2). Small spheres (100 to $750 \mathrm{~nm}$ diameter) of silico-calcic glass had an average $\mathrm{Al}: \mathrm{Si}$ ratio of $0.5 \pm 0.1$, an average $\mathrm{Ca}$ :Si ratio of $0.6 \pm 0.3$ and variable contents of alkaline $(\mathrm{Mg})$ and metal (Fe, Mn) elements (Table 3) . Some phases with a 1:1 Ca:Si ratio were assigned to wollastonite. These glass-like spheres were often surrounded with aluminosilicate phases comprising 50-nm fibrous components (Figure 7). Fibrous phases could correspond to the 'allophane-like' phases. They were more depleted in $\mathrm{Ca}$ than the glass-like phases with an average $\mathrm{Ca}: \mathrm{Si}$ ratio of $0.1 \pm 0.1$ and an average $\mathrm{Al}: \mathrm{Si}$ ratio of $0.6 \pm 0.2$ (Table 3). Some clay minerals (Fe chlorites, berthierines and kaolinite) and quartz were detected as minor phases by XRD in some layers of group 1 (Figure 6 and Table 2).

Table 3 Average elemental composition of aluminosilicate spherical and fibrous phases. Average content and standard deviation were calculated from the TEM-EDS analyses performed on $n$ phases in layers $1,2,4,11$ and to a lesser extent, layers 5 and 7.

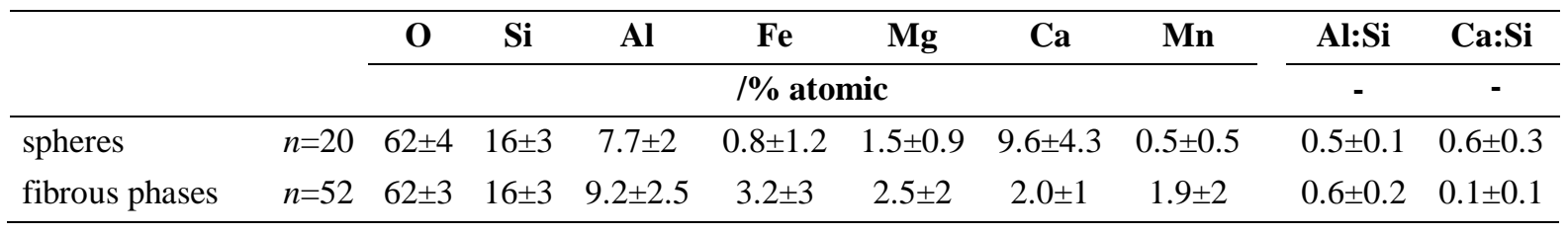
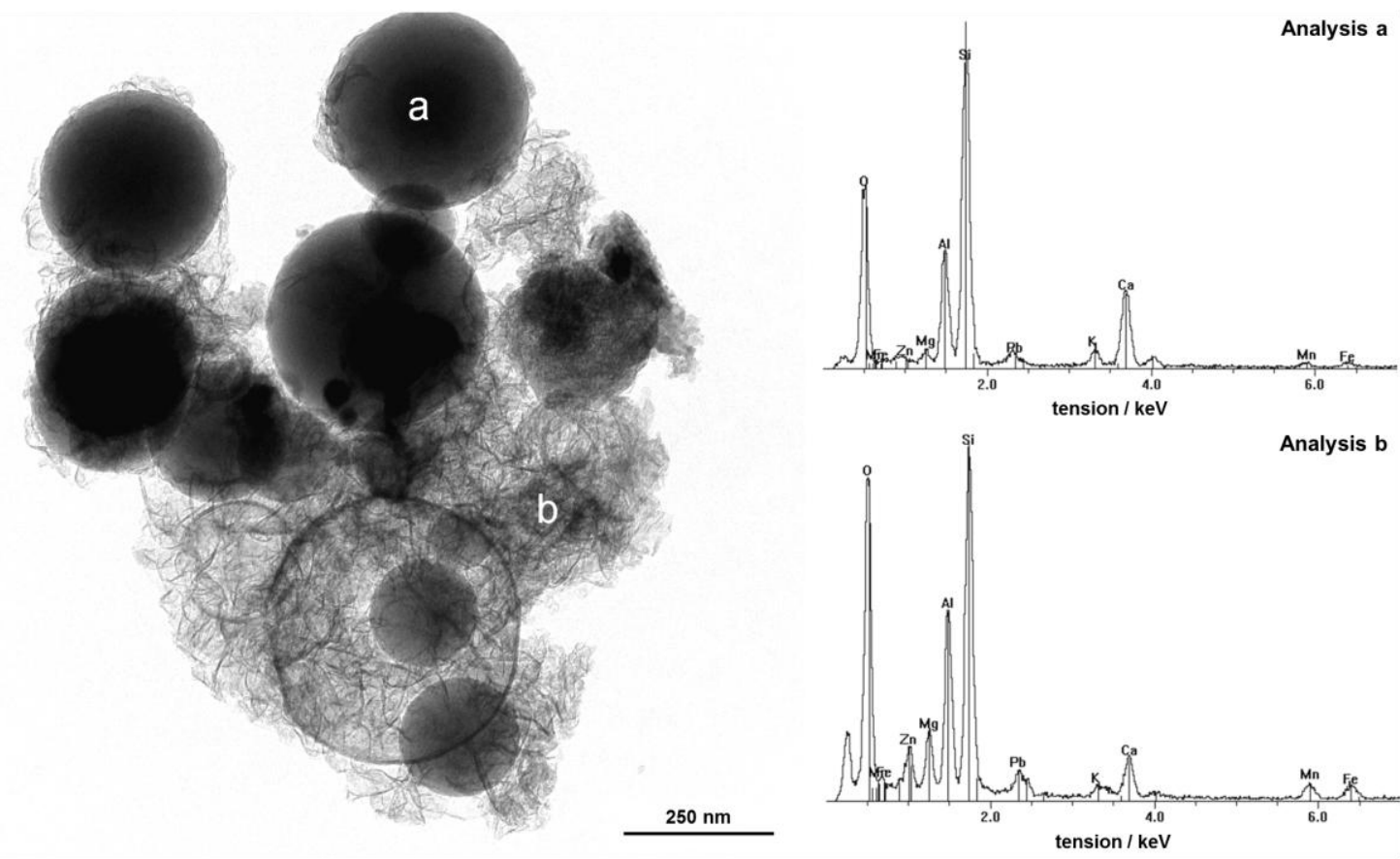

Figure 7 Aluminosilicate phases observed by TEM-EDS in layer 4 (group 1). Silico-calcic glass-like spherical phases (a) surrounded by fibrous crystalline aluminosilicate phases (b). 
Iron and $\mathrm{Mn}$ oxides and hydroxides had different levels of oxidation and crystallinity as well as various morphologies. Manganese (hydr)oxides were the major phases in layers 5 and 7 (group 2). They appeared as filled spheres (plerospheres, 10$50 \mu \mathrm{m}$ in diameter) (Figure 8a-c), and in some cases displayed concentric zonings reflecting a change of composition (Figure 8b). The smaller phases $(<5 \mu \mathrm{m})$ had a poorly crystalline fibrous structure (Figure 9a). However, some crystalline phases of manganese oxide $_{2}$ were observed (Figure 9b) and detected with XRD (peak corresponding to $4.70 \AA$ interplanar spacings) in group 2 layers (3, 4, 5 and 8) (Figure 6). The observed phases were mainly made of $\mathrm{MnO}_{2}$ and to a lesser extent $\mathrm{MnO}$ and also contained observable amounts of $\mathrm{Si}, \mathrm{Al}$ and other metals (EDS spectra in Figures 8 and 9).

Several Fe (hydr)oxides, such as ferrihydrite $\left(5 \mathrm{Fe}_{2} \mathrm{O}_{3} \cdot 9 \mathrm{H}_{2} \mathrm{O}\right)$, haematite $\left(\mathrm{Fe}_{3} \mathrm{O}_{4}\right)$ and goethite $(\mathrm{FeO}(\mathrm{OH})$ ), were detected by XRD (Figure 6) and Mössbauer spectroscopy (Figure 10a and Table 4) and analysed by SEM- and TEM-EDS (Figure 10c), in particular in group 1 layers (1, 2 and 11). Iron was also present in its metallic form (Figure 10a and Table 4). Plerospheres (25-100 $\mu \mathrm{m}$ in diameter) made of reduced $\mathrm{Fe}(\mathrm{Fe}$ or $\mathrm{FeO}$ ) were observed in layer 1 (Figure 10b). Some Fe- and Mnbearing compounds showed a strong compositional heterogeneity and a concentric structure. Several phases were observed with an Fe (hydr)oxide core and a Mn-rich shell.

Table 4 Mössbauer parameters for three layers (1,2 and 11) along the Technosol profile. Each line corresponds to a Fe-bearing phase or a $\mathrm{Fe}$ site with characteristic parameters: isomer shift with respect to metallic $\alpha$-Fe at room temperature $(\delta)$, quadrupole splitting $(\Delta)$, hyperfine magnetic field $(H)$ and their relative abundance (RA) and their content calculated with respect from the total $\mathrm{Fe}$ content. Spectra were recorded at room temperature.

\begin{tabular}{|c|c|c|c|c|c|c|}
\hline layer & phase or Fe site & $\begin{array}{c}\delta \\
/ \mathrm{mm} \mathrm{s}^{-1}\end{array}$ & $\begin{array}{c}\Delta \\
/ \mathrm{mm} \mathrm{s}^{-1}\end{array}$ & $\begin{array}{c}\mathrm{H} \\
/ \mathrm{kOe}\end{array}$ & $\begin{array}{c}\mathrm{RA} \\
1 \% \mathrm{Fe}_{\text {total }}\end{array}$ & $\begin{array}{l}\text { content } \\
/ \mathrm{g} \mathrm{kg}^{-1}\end{array}$ \\
\hline layer 1 & $\mathrm{Fe}$ (III) - ferrihydrite & 0.28 & 0.86 & - & 19 & 41 \\
\hline \multirow[t]{5}{*}{$(0-18 \mathrm{~cm})$} & $\mathrm{Fe}(\mathrm{II})$ - silicate & 1.20 & 2.28 & - & 14 & 30 \\
\hline & $\mathrm{Fe}(\mathrm{III})$ - silicate & 0.57 & 1.1 & - & 8 & 17 \\
\hline & goethite & $0.34-0.69$ & - & $267-460$ & 33 & 71 \\
\hline & haematite & 0.27 & - & 482 & 22 & 47 \\
\hline & metallic Fe & -0.01 & - & 329 & 4 & 9 \\
\hline \multirow[t]{5}{*}{$\begin{array}{c}\text { layer } 2 \\
(18-26 \mathrm{~cm})\end{array}$} & $\begin{array}{l}\mathrm{Fe}(\mathrm{III}) \text { - ferrihydrite } \\
+\mathrm{Fe}(\mathrm{III}) \text { - silicate }\end{array}$ & 0.40 & 0.86 & - & 34 & 44 \\
\hline & $\mathrm{Fe}(\mathrm{II})$ - silicate & 1.13 & 2.53 & - & 15 & 20 \\
\hline & goethite & $0.44-0.64$ & - & $269-337$ & 21 & 27 \\
\hline & haematite & 0.49 & - & 482 & 18 & 24 \\
\hline & metallic Fe & -0.04 & - & 327 & 7 & 9 \\
\hline \multirow[t]{5}{*}{$\begin{array}{c}\text { layer } 11 \\
(165-180 \mathrm{~cm})\end{array}$} & $\begin{array}{l}\mathrm{Fe}(\mathrm{III}) \text { - ferrihydrite } \\
+\mathrm{Fe}(\mathrm{III}) \text { - silicate }\end{array}$ & 0.37 & 0.74 & - & 42 & 51 \\
\hline & $\mathrm{Fe}(\mathrm{II})$ - silicate & 1.18 & 2.47 & - & 11 & 13 \\
\hline & goethite & $0.32-0.48$ & - & $420-450$ & 22 & 27 \\
\hline & metallic Fe & 0.002 & - & 330 & 15 & 18 \\
\hline & haematite & 0.34 & - & 493 & 10 & 12 \\
\hline
\end{tabular}



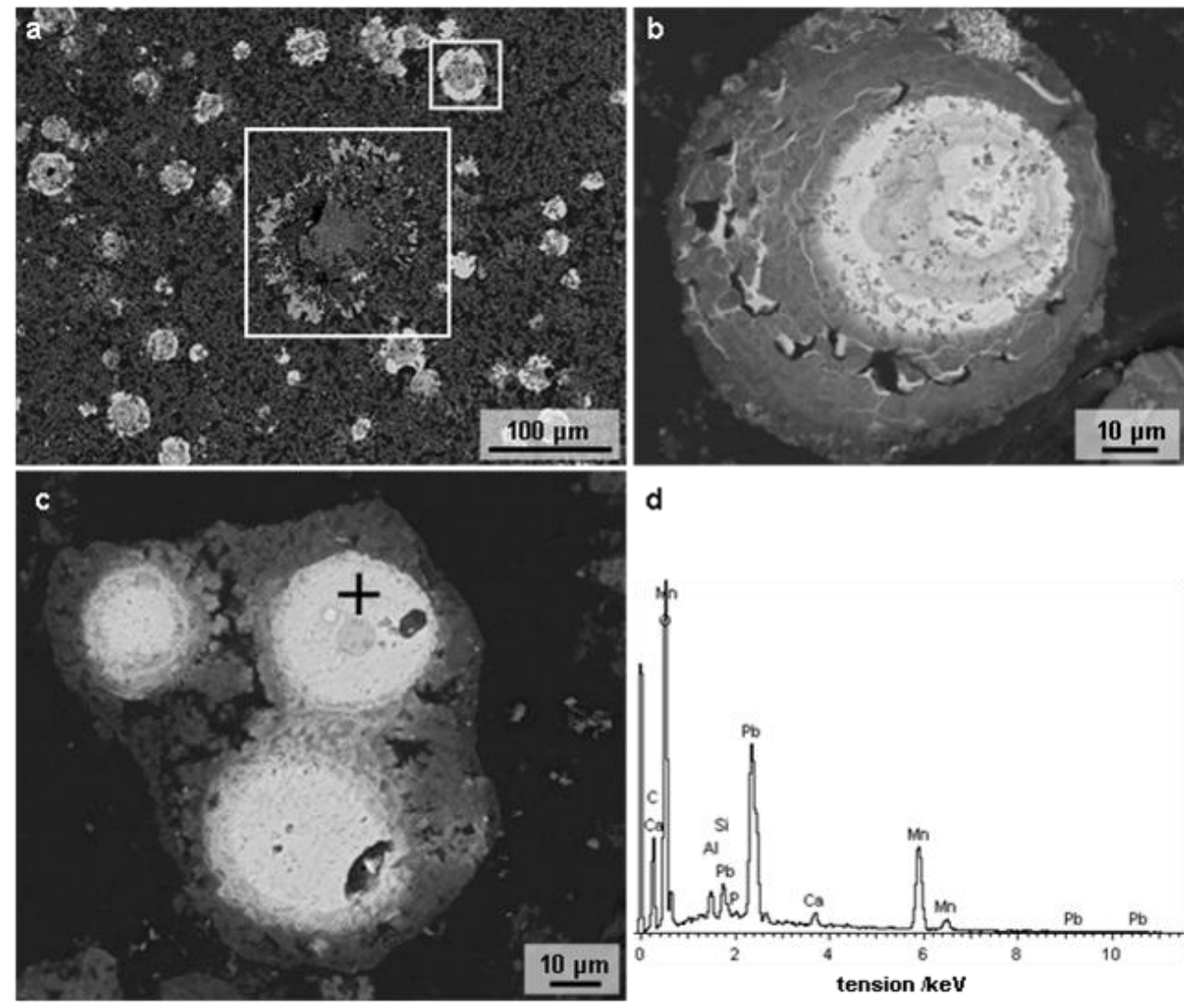

d

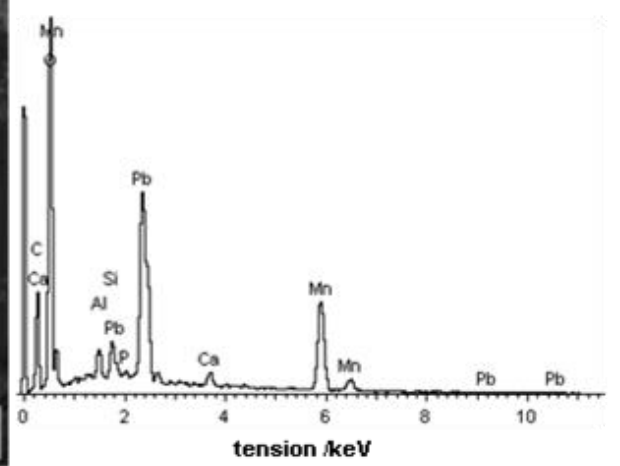

Figure 8 Manganese-bearing phases on polished sections in layers 5 and 7 (group 2) observed by SEM-EDS: (a) plerospheres of Mn (hydr)oxides surrounded by a aluminosilicate matrix and $\mathrm{CaCO}_{3}$ crystals surrounded a Mn-bearing compound (layer 5), (b) plerosphere of Mn (hydr)oxides showing concentric zoning (layer 7) and (c) plerospheres of Mn (hydr)oxides containing Al, Si and metals (spectrum (d)) surrounded by weathered products (layer 7).
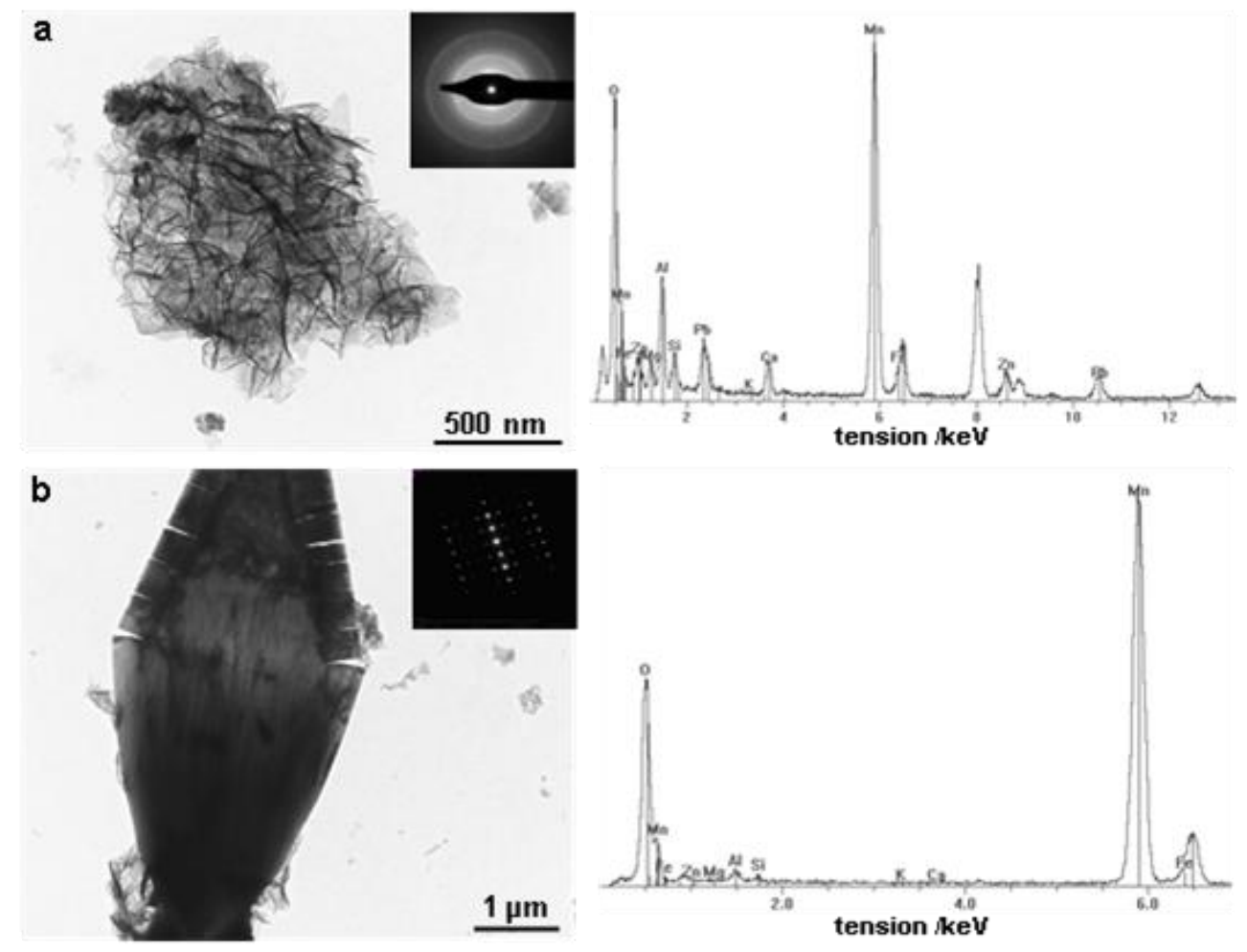

Figure 9 Manganese-bearing phases displaying different levels of crystallinity and forms observed by TEM-EDS: (a) fibrous and poorly crystalline $\mathrm{Mn}$ (hydr)oxide containing $\mathrm{Al}, \mathrm{Ca}, \mathrm{Si}$ and metals (layer 1) and (b) crystalline $\mathrm{Mn}$ oxide of $\mathrm{MnO}_{2}$ type (d=4,70 $\mathrm{A}$ ) (layer 5) (group 2). 

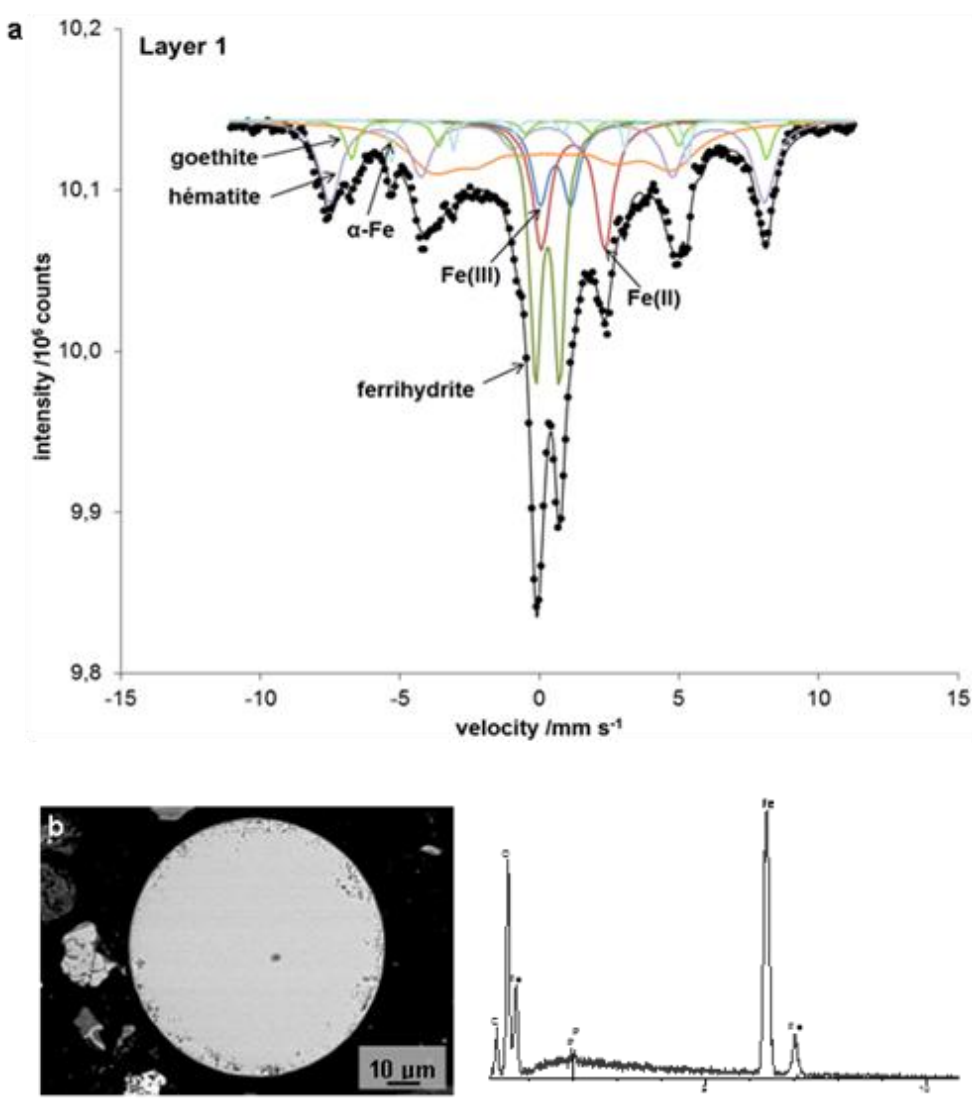

c

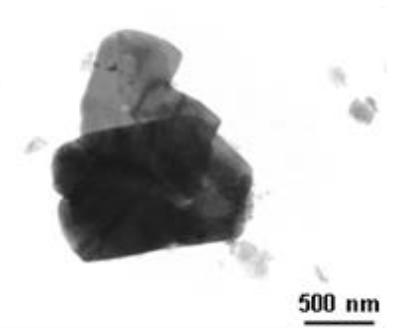

Figure 10 Iron-bearing phases detected in layer 1 (0-18 cm): (a) Mössbauer spectrum recorded at room temperature showing the presence of Fe (hydr)oxides, metallic $\mathrm{Fe}$, and of $\mathrm{Fe}(\mathrm{II})$ and $\mathrm{Fe}(\mathrm{III})$ probably in silicates, (b) plerosphere of Fe oxides (FeO) observed by SEM-EDS and (c) haematite $\left(\mathrm{Fe}_{3} \mathrm{O}_{4}\right)$ observed by TEMEDS.

Sulphate phases, such as gypsum, anhydrite and ettringite were detected by XRD in deeper layers 11 and 12 (group 1). Observations revealed also the presence of $\mathrm{Ba}$ sulphates in layers 7 (group 2) and 11 (group 1). These phases appeared as automorphous crystals (10-30 $\mu \mathrm{m})$ and contained small amounts of strontium (Sr). Sulphate phases, such as gypsum, anhydrite and ettringite were detected by XRD in deeper layers 11 and 12 (group 1). Observations revealed also the presence of $\mathrm{Ba}$ sulphates in layers 7 (group 2) and 11 (group 1). These phases appeared as automorphous crystals $(10-30 \mu \mathrm{m})$ and contained small amounts of strontium (Sr). 
Total cyanide contents varied along the profile and seemed to be greater in the layers of group 1. Contents were as much as $1179 \mathrm{mg} \mathrm{CN} \mathrm{kg}^{-1}$ dried soil in the layer at 35-40 cm (corresponding to layer 2), $435 \mathrm{mg} \mathrm{CN} \mathrm{kg}^{-1}$ at $40-55 \mathrm{~cm}, 113 \mathrm{mg} \mathrm{CN} \mathrm{kg}^{-1}$ at $55-70 \mathrm{~cm}$ (corresponding to layer 3) and $3445 \mathrm{mg} \mathrm{CN} \mathrm{kg}^{-1}$ at $70-80 \mathrm{~cm}$ (corresponding to layer 4). In the latter, available cyanides were present at $4 \mathrm{mg} \mathrm{CN}$ $\mathrm{kg}^{-1}$, showing the very poor mobility of cyanide compounds in the soil. X-ray diffraction patterns and DRIFTS spectra indicated the presence of group 1 of potassium zinc hexacyanoferrate(II) nonahydrate $\left(\mathrm{K}_{2} \mathrm{Zn}_{3}\left(\mathrm{Fe}(\mathrm{CN})_{6}\right)_{2} .9 \mathrm{H}_{2} \mathrm{O}\right)$ in some layers. This finding was supported by the presence of a light absorption band between 2094 and $2105 \mathrm{~cm}^{-1}$ on DRIFTS spectra of the layers 4, 9 (Figure 11b), 11 and 12, which corresponds to the stretching band of the triple bound $-\mathrm{C} \equiv \mathrm{N}$ in this cyanide compound (Rennert et al., 2007). Diffractograms of these layers showed peaks corresponding to $4.06 \AA$ interplanar spacings and, to a lesser extent, 5.41 and $4.51 \AA$ (Figure 11a), which are typical of this cyanide compound (Mansfeldt \& Dohrmann, 2001).
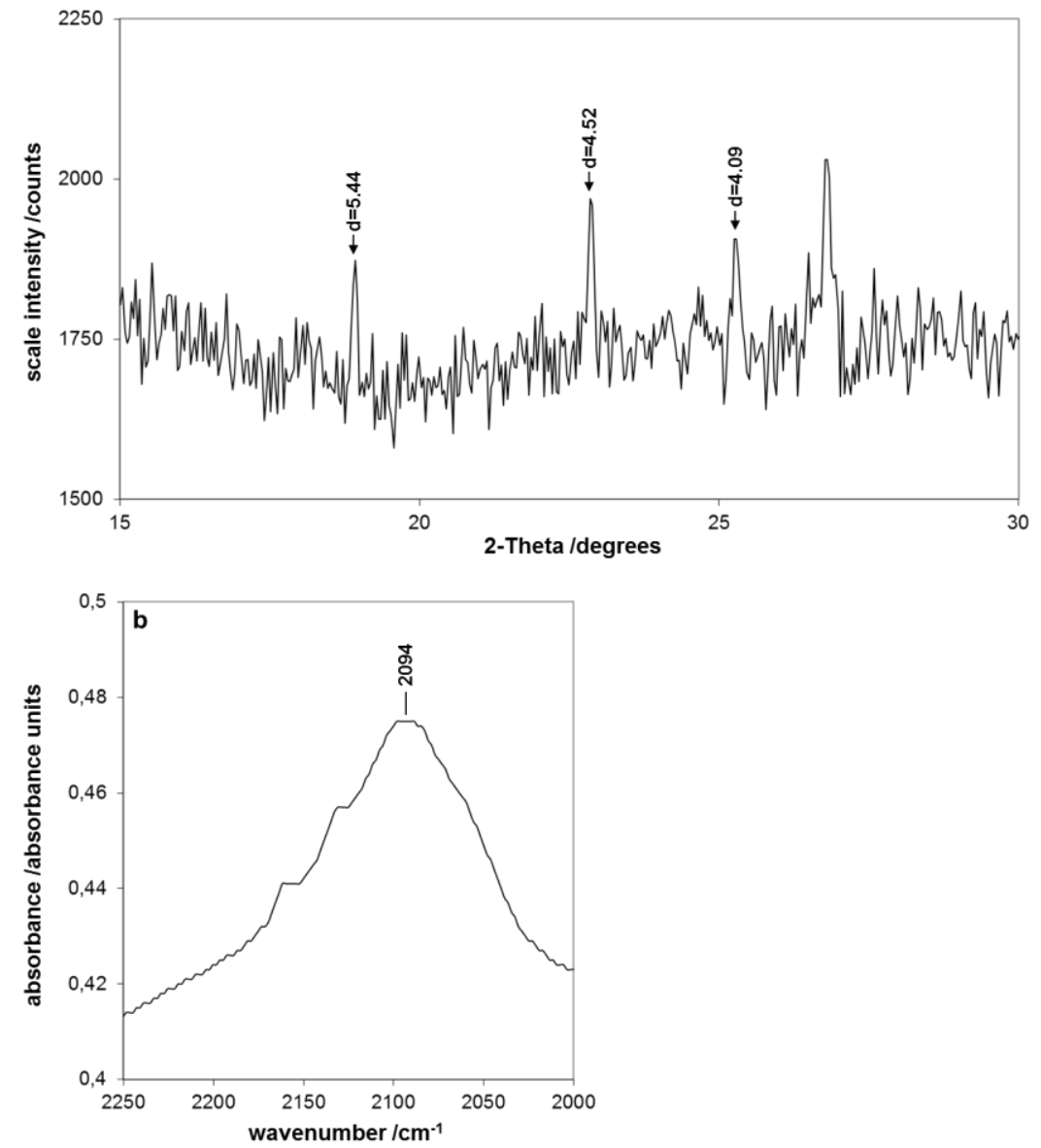

Figure 11 Details of XRD patterns: (a) and FTIR spectrum and (b) highlighting the presence of a ferrocyanide compound $\mathrm{K}_{2} \mathrm{Zn}_{3}\left(\mathrm{Fe}(\mathrm{CN})_{6}\right)_{2} .9 \mathrm{H}_{2} \mathrm{O}$ in the layer $9(135-140 \mathrm{~cm})$ (group 1). The d spacings in $\AA$ are indicated on the peaks corresponding to this compound. 


\section{Discussion}

The Technosol is the result of a series of successive processes, from the deposition and formation of parental materials generated by the iron and steel industry to the early pedogenetic processes (weathering, transfer and accumulation) under the influence of environmental factors for approximately half a century. From analysis of the structure and mineral phases, combined with the knowledge of the industrial processes (particle (trans)formation in the blast furnace, sludge production and sludge discharge, the origin and transformations of the constituents can be inferred and a chronological reconstitution of the formation of the Technosol proposed.

\section{(Trans)formation processes of particles in the blast furnace}

Some mineral phases in the Technosol could result from the fine particles leaving the blast furnace during the introduction of the raw materials (ores, fuel, fluxes). For instance, the Fe ore formerly used by the steel industry in Lorraine ('Minette') is composed of goethite, Fe-bearing chlorites and calcite (Dagallier et al., 2002).

However, most minerals are decomposed in the blast furnace and fine particles are (trans)formed by the thermic and reduction processes. The large range of $\mathrm{Fe}$ oxides and particularly the presence of metallic Fe in the Technosol could result from the more or less complete reduction of Fe oxides (Truffaut, 1989). At temperatures from 1200 to $1600^{\circ} \mathrm{C}$, ore melts and some compounds are volatilized and partly evacuated with gas at the top of the blast furnace. Glass-like phases originating from the fast cooling of a silicate liquid and spherical phases from the solidification of droplets are present in suspension in the gas (Vassilev \& Vassileva, 1996). The presence of Mn oxide in the Technosol could be explained by the condensation and oxidation of volatilized Mn during upflow in the blast furnace which forms micronic particles $(1-10 \mu \mathrm{m})$ (Truffaut, 1989). Carbon from the coke and $\mathrm{N}$ from the blown pre-heated air react to form hydrogen cyanide $(\mathrm{HCN})$, which is also partly evacuated with the gas.

\section{Formation and settling of blast furnace sludge}

During wet cleaning of the gas containing particulate materials, condensing processes continue, and other chemical reactions occur in contact with water and the atmosphere (hydration, carbonation), resulting in mineralogical transformations. For instance, alkali or even more complex cyanides could be formed, such as $\mathrm{K}_{2} \mathrm{Zn}_{3}\left(\mathrm{Fe}(\mathrm{CN})_{6}\right)_{2} \cdot 9 \mathrm{H}_{2} \mathrm{O}$, which is a typical compound of blast furnace sludge (Mansfeldt \& Dohrmann, 2001). The stratified deposit with an alternation of dark layers rich in $\mathrm{Mn}$ (hydr)oxides and lighter-coloured layers dominated by aluminosilicates, carbonates and Fe (hydr)oxides resulted from the settling of successive sludge supplies. Sludge composition varied according to the raw materials and industrial processes, and black layers were probably connected with ferromanganese production. Moreover, other wastes used in the iron and steel industry could have been deposited in the pond. 


\section{Signs of evolution processes of the industrial parental materials}

The presence of cracks, crossing the laminar structure of some layers, at the limit between two layers suggests that deposition was not a continuous process and there were periods of desiccation between supplies of liquid sludge supplies. The andic properties (low bulk density, large porosity and water retention capacity) developed by these materials (Huot et al., 2013) favour shrinkage with drying (Bartoli et al., 2007). Suspension flows have filled cracks with the material above, and displaced finer particles explaining the particular structure in some areas. Coatings of Mn-rich material or calcite in some cracks reflected solute movements and seemed to be restricted to specific layers or at the interface between two consecutive layers. The presence of $\mathrm{Ca}$ sulphates in deeper layers only could result from leaching processes through the soil profile.

Mineral weathering and precipitation of new phases were recorded. Coatings rich in $\mathrm{Mn}$ originated probably from the solubilization of $\mathrm{Mn}$ and $\mathrm{Fe}$ in reduced environments allowing their transport, followed by their precipitation in more oxygenated area (along cracks) as is commonly observed in seasonally flooding soils (Richardson \& Vepraskas, 2001). These phenomena may explain the formation of $\mathrm{Mn}$ nodules in soil (McKenzie, 1989). Also, black Mn precipitates present as upward or downward features (dendrites and droplets, respectively) might be evidence of diffusion from the Mn-rich coatings towards the Mn-depleted adjacent materials. Dissolved $\mathrm{Mn}^{2+}$ might have been transported by mass flow under the action of the gravity or capillarity in the vicinity of the cracks.

Among secondary phases are carbonates as suggested by calcite coatings. Calcite was formed from hydrolysis of $\mathrm{Ca}$ oxides or calcic silicates and carbonation in contact with water and atmospheric $\mathrm{CO}_{2}$. Similarly, $\mathrm{Fe}$ released from primary phases contributed to the formation of new phases, such as ferrihydrite (Schwertmann \& Taylor, 1989) or complexes with cyanides and then $\mathrm{K}$ and $\mathrm{Zn}$ to form $\mathrm{K}_{2} \mathrm{Zn}_{3}\left[\mathrm{Fe}(\mathrm{CN})_{6}\right]_{2} \cdot 9 \mathrm{H}_{2} \mathrm{O}$. Also, weakly crystalline fibrous aluminosilicates probably originate from $\mathrm{Al}$ and $\mathrm{Si}$ released by weathering of glass-like phases. We can assume that sludge $\mathrm{pH}$ was initially high and controlled by the reaction of $\mathrm{Ca}$ and alkali oxides, and then decreased in the presence of atmospheric $\mathrm{CO}_{2}$ to reach its current value of 8 (Huot et al., 2013). A high pH (>9) favoured the dissolution of both $\mathrm{Al}$ and Si from silicate glass and industrial aluminosilicates, whereas a decrease in $\mathrm{pH}$ caused the precipitation of secondary aluminosilicates (Zevenbergen et al., 1999). Zeolites could also be formed in such an environment from Si released at high pH (Sauer \& Burghardt, 2006).

After the termination of sludge discharges, organisms have colonized the deposit, which is currently covered by a forest. As a consequence, organic matter has accumulated at the top of the soil profile, and a thick organo-mineral horizon has developed with the mixing of organic and mineral phases resulting from the industrial process (glass, metallic $\mathrm{Fe}$ compounds). Biological activity (roots, fauna) is observable down the profile but is more intense in the surface layer. Roots are present 
in all layers and develop preferentially in the cracks and macro-pores or at the boundary between two layers.

\section{Proposed outline of pedogenesis on the iron deposit}

Physical and chemical processes occurred preferentially at the top of the layers or at the interface of two consecutive layers. This suggests that pedogenetic change was initiated during the pond filling, which left sludge layers under the direct influence of the climate. At this time, materials in the pond underwent dramatic changes in their surrounding water environment. Wetting-drying cycles, producing shrinkage and oxidation, were probably the driving factors of dissolution and precipitation, which developed primarily in the cracks. Also, during this period of intense change, the high $\mathrm{pH}$ contributed to accelerated weathering of industrial aluminosilicate phases. This first step of weathering depended on the time span between two successive sludge supplies.

The spreading of a new sludge layer with a different composition caused infilling of the cracks by fine material and could induce a new cycle of reduction reactions along with the diffusion of solutes, leaving traces at the interface between two layers and around the crack coatings. Gradual burying of the sludge layers modified the physical and chemical conditions (lower oxygenation, subsidence), and reduced the influence of climate in the deeper layers. Hence, the initial physical and chemical pedogenetic processes initiated during the pond filling either stopped or were substituted by new processes (diffusion, root activity). In the absence of roots, drying in deeper layers is unlikely because of the large water retention capacity of these materials (Huot et al., 2013). So, some mineral transformations or mass and solute transfers seem to be evidence of an early stage of pedogenesis, producing 'fossilized' pedogenetic structures with no further changed occurring.

Later, biological activity became the new driving factor of pedogenesis of thisTechnosol, particularly in the upper layers. Roots as well as associated microorganisms and fauna have colonized the deeper layers taking advantage of the previous steps of weathering, such as in cracks. Organisms may play a role in the weathering and evolution of the material as they contribute to the development of flow pathways, modify chemical ambiance ( $\mathrm{pH}$, redox potential) in the rhizosphere and create organo-mineral associations.

\section{Conclusions}

The profile of a Technosol developing on a deposit of blast furnace sludge, and currently supporting a forested ecosystem, was investigated by the analysis of the structure at different scales and the mineral phases. This approach, combined with the knowledge of the industrial operations and of pedogenetic processes occurring in 'natural' soils, enabled us to infer the origin and transformations of the constituents and to propose a scenario for the Technosol formation. 
The investigations provided evidence of an evolution of the industrial parental materials following several stages with areas of more intense changes (interfaces between layers, cracks). An early stage, and driven by drying-wetting cycles and changes of physico-chemical conditions (redox, $\mathrm{pH}$ ) occurred during the deposition of sludge and produced shrinkage, mass and solute transport and mineral transformation. Then, gradual burying changed the conditions further, reducing the influence of climate as driver of pedogenesis. The current changes are driven mainly by biological processes, as is evident in the accumulation of organic matter in the upper layer. A study of the role of roots, which are present throughout the soil profile, is underway.

Tracing the formation of Technosols provides information on pedogenetic processes occurring in these soils and helps us to understand their functioning and to predict their evolution better. Characterization of the anthropic constituents and knowledge of the specificity of pedogenetic processes in such soils appeared to be relevant criteria for the establishment of a functional classification of Technosols.

\section{Acknowledgements}

This work was conducted within the framework of the GISFI program (www.gisfi.fr) and supported by the Région Lorraine, Institut Carnot Energie Environnement Lorraine (ICEEL) and ArcelorMittal Real Estate France (AMREF). The authors wish to thank Patrick Charbonnier and Emmanuelle Depré (AMREF) for their advice and help, Jean-Claude Bégin, Adeline Bouchard and Romain Goudon (LSE) and Cindy Messana and Lucas Charrois (GISFI) for the sampling and the production of thin sections, Mustapha Abdelmoula (LCPME) for Mössbauer spectroscopy analyses, Odile Barrès (LEM) for IR spectroscopy analyses, Guirec Ollivier (LEM) for XRD analyses, Jaafar Ghanbaja, Sandrine Mathieu and Ludovic Mouton (SCMEM) for SEM-EDS and TEM-EDS analyses, M.C. Rouillier (LEM) for the cyanide analyses and Camille Morel for her work on mineralogical characterization.

\section{References}

AFES. 2008. Référentiel Pédologique 2008. Editions Quae., Versailles, France.

AFNOR XP X31-430. 2001. Qualité du sol: dosage des cyanures. http://www.afnor.org/en/certification

Bartoli, F., Begin, J.C., Burtin, G. \& Schouller, E. 2007. Shrinkage of initially very wet soil blocks, cores and clods from a range of European Andosol horizons. European Journal of Soil Science, 58, 378-392.

Bullock, P., Fedoroff, N. Jongerius, A. Stoops, G. \& Tursina, T. 1985. Handbook for Soil Thin Section Description. Waine Research, England.

Carignan, J., Hild, P., Mevelle, G., Morel, J. \& Yeghicheyan. D. 2001. Routine analyses of trace elements in geological samples using flow injection and low 
pressure on-line liquid chromatography coupled to icp-ms: A study of geochemical reference materials BR, DR-N, UB-N, AN-G and GH. Geostandards \& Geoanalytical Research, 25, 187-198.

Dagallier, G., Grgic, D. \& Homand, F. 2002. Caractérisation minéralogique et microtexturale du vieillissement anthropique du minerai de fer lorrain. Comptes Rendus Geoscience, 334, 455-462.

De Kimpe, C. R. \& Morel, J. L. 2000. Urban soil management: a growing concern. Soil Science, 165, 31-40.

Ettler, V., Legendre, O., Bodenan, F. \& Touray, J. C. 2001. Primary phases and natural weathering of old lead-zinc pyrometallurgical slag from Pribram, Czech Republic. Canadian Mineralogist, 39, 873-888.

Ettler, V., Johan, Z. \& Hradil, D. 2003. Natural alteration products of sulphide mattes from primary lead smelting. Comptes Rendus Geoscience, 335, 1013-1020.

Gregurek, D., Reimann, C. \& Stumpfl, E.F. 1998. Mineralogical fingerprints of industrial emissions - an example from Ni mining and smelting on the Kola Peninsula, NW Russia. Science of the Total Environment, 221,189-200.

Hartmann, P., Fleige, H. \& Horn, R. 2010. Changes in soil physical properties of forest floor horizons due to long-term deposition of lignite fly ash. Journal of Soils \& Sediments, 10, 231-239.

Huot, H., Simonnot, M. O., Marion, P., Yvon, J., De Donato, P. \& J. L. Morel. 2013. Characteristics and potential pedogenetic processes of a Technosol developing on iron industry deposits. Journal of Soils \& Sediments, 13, 555-568.

IUSS Working Group WRB. 2006. World Reference Base for Soil Resources. World Soil Resources Reports, FAO, Rome.

Jenny, H. 1941. Factors of Soil Formation. McGraw-Hill Book Co, New York.

Lehmann, A. 2006. Technosols and other proposals on urban soils for the WRB (World Reference Base for Soil Resources). International Agrophysics, 20, 129-134.

Mansfeldt, T. \& Dohrmann, R. 2001. Identification of a crystalline cyanide-containing compound in blast furnace sludge deposits. Journal of Environmental Quality, 30, $1927-1932$.

Mansfeldt, T. \& Dohrmann, R. 2004. Chemical and mineralogical characterization of blast-furnace sludge from an abandoned landfill. Environmental Science \& Technology, 38, 5977-5984.

McKenzie, R.M. 1989. Manganese oxides and hydroxides. In: Minerals in Soil Environments (eds J.B. Dixon \& S.B Weed), pp. 439-461. Soil Science Society of America. Madison, Wisconsin.

Mehra, O. P. \& Jackson, M. L. 1960. Iron oxide removal from soils and clays by a dithionite-citrate system buffered with sodium bicarbonate. Proceedings 7 th International Conference on Clays., 5, 317-327..

Monserié, M. F., Watteau, F., Villemin, G., Ouvrard, S. \& Morel, J. L. 2009. Technosol genesis: identification of organo-mineral associations in a young 
Technosol derived from coking plant waste materials. Journal of Soils \& Sediments, 9, 537-546.

Rennert, T., Kaufhold, S. \& Mansfeldt, T. 2007. Identification of Iron-Cyanide Complexes in Contaminated Soils and Wastes by Fourier Transform Infrared Spectroscopy. Environmental Science \& Technology, 41, 5266-5270.

Richardson, J.L. \& Vepraskas, M.J. 2001. Wetland Soils: Genesis, Hydrology, Landscapes, and Classification. CRC Press, Boca Raton, United States.

Rossiter, D.G. 2007. Classification of urban and industrial soils in the World Reference Base for Soil Resources. Journal of Soils \& Sediments, 7, 96-100.

Saffarzadeh, A., Shimaoka, T., Wei, Y., Gardner, K. H. \& Musselman C. N. 2011. Impacts of natural weathering on the transformation/neoformation processes in landfilled MSWI bottom ash: A geoenvironmental perspective. Waste Management, 31, 2440-2454.

Sauer, D. \& Burghardt, W. 2006. The occurrence and distribution of various forms of silica and zeolites in soils developed from wastes of iron production. Catena, 65, 247-257.

Schwartz, C., Florentin, L., Charpentier, D., Muzika, S. \& More, J.-L. 2001. Le pédologue en milieux industriels et urbains. I. Sols d'une friche industrielle. Etude et Gestion des Sols, 8, 135-148.

Schwertmann, U. \& Taylor, R.M. 1989. Iron Oxides. In: Minerals in Soil Environments (eds J.B. Dixon \& S.B Weed), pp. 379-427. Soil Science Society of America. Madison, Wisconsin.

Séré, G., Schwartz, C., Ouvrard, S., Renat, J.C., Watteau, F.,Villemin, G. et al. 2010. Early pedogenic evolution of constructed Technosols. Journal of Soils \& Sediments, 10, 1246-1254.

Sourkova, M., Frouz, J. \& Santruckova, H. 2005. Accumulation of carbon, nitrogen and phosphorus during soil formation on alder spoil heaps after brown-coal mining, near Sokolov (Czech Republic). Geoderma, 124, 203-214.

Stoops, G., Marcelino, V. \& Mees F. 2010. Interpretation of Micromorphological Features of Soils and Regoliths. Elsevier, Amsterdam, Netherlands.

Tamm, O. 1922. Eine methode zur bestimmung der anorganischen komponente des gelkomplexes im boden. Meddelanden fran Statens Skogsförsöksanstalt, 19, 385-404.

Truffaut, E. (ed.) 1989. Ferromanganèse élaboré au haut fourneau. Techniques de l'ingénieur, Elaboration et recyclage métaux. Techniques de l'Ingénieur, Paris, France.

Truffaut, E. 2004. La fabrication du ferro-manganèse au haut-fourneau en France, 1875-2003. Naissance, vie et mort d'un procédé industriel. http://soleildacier.ouvaton.org/savoir/fr/DNA02-S2-W.pdf.

Uzarowicz, L. \& Skiba, S. 2011. Technogenic soils developed on mine spoils containing iron sulphides: Mineral transformations as an indicator of pedogenesis. Geoderma, 163, 95-108. 
Van Breemen, N. \& Buurman, P. 2002. Soil Formation. Kluwer Academic Pub, Dordrecht, Netherlands.

Vassilev, S.V. \& Vassileva, C.G. 1996. Mineralogy of combustion wastes from coalfired power stations. Fuel Processing Technology, 47, 261-280.

Yvon, J., Antenucci, D., Jdid, E.A., Lorenzi, G., Dutre, V., Leclerq, D, et al. 2006. Long-term stability in landfills of Municipal Solid Waste Incineration fly ashes solidified/stabilized by hydraulic binders. Journal of Geochemical Exploration, 90, 143-155.

Zevenbergen, C., Bradley, J.P., Van Reeuwijk, L.P., Shyam, A.K., Hjelmar, O. \& Comans, R.N.J. 1999. Clay formation and metal fixation during weathering of coal fly ash. Environmental Science \& Technology, 33, 3405-3409.

Zikeli, S., Jahn, R. \& Kastler, M. 2002. Initial soil development in lignite ash landfills and settling ponds in Saxony-Anhalt, Germany. Journal of Plant Nutrition \& Soil Science, 165, 530-536. 